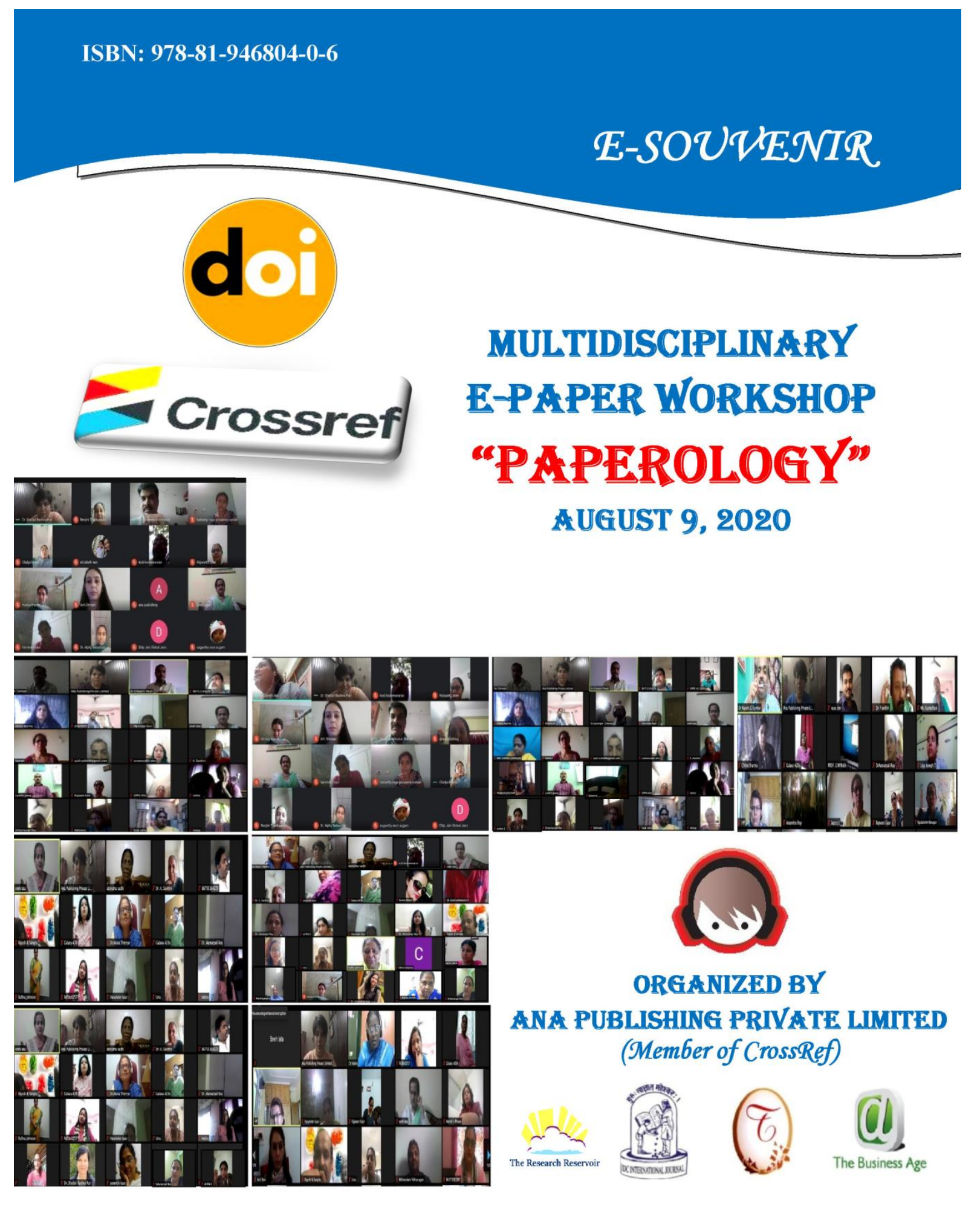




\section{ANA PUBLISHING PRIVATE LIMITED}

\section{MULTIDISCIPLINARY E-PAPER WORKSHOP - ABSTRACTS}

ISBN 978-81-946804-0-6

This is E-Souvenir of a webinar entitled "Multidisciplinary E-Paper Workshop Paperology" organized by Ana Publishing Private Limited and held on Aug. 9, 2020 through Zoom Interactive Meeting Platform.

\section{EDITORLAL BOARD}

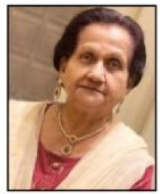

Mrs. Sneh Lata

Founding Editor

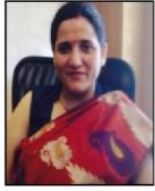

Dr. Aamarpali Roy

Editor in Chief

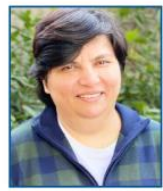

Dr. Shaifali Rachna Puri

Managing Editor

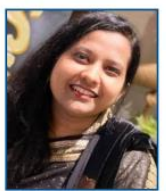

Dr. Amandeep Kaur

Executive Editor

\section{PANEL OF EXPERTS}

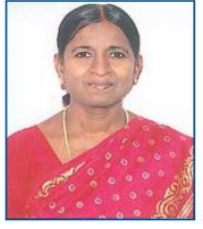

Dr. C Nalini Jeyavantha Principal

Sacred Heart Nursing

College, Thashildar, Madurai

\section{ADVISORY BOARD}

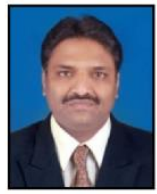

Dr. Velmurgan

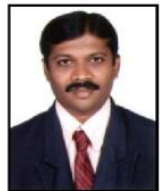

Dr. Ian Clement

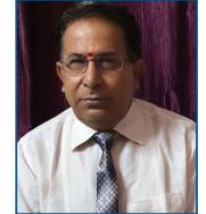

Dr. CP Sharma

Principal

BDM College of Nursing

Chhuchhakwas, Jhajhar, Haryana

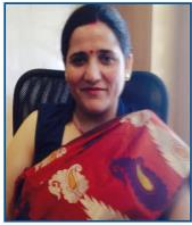

Dr. Aamarpali Roy

Editor in Chief

Ana Publishing Private Limited

Copyright @Ana Publishing Private Limited 2020-Multidisciplinary E-Paper Workshop "Paperology"

ISBN: 978-81-946804-()-6

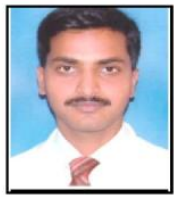

Dr. Chetan S Patali

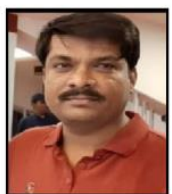

Dr. Susheel Kumar Ronad 


\section{DISTINGUISHED DIGNITARIES}

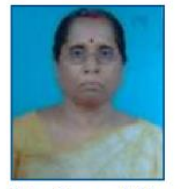

Dr. Laxmi Rana

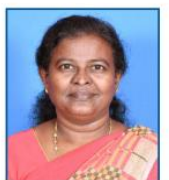

Dr. J Jasmine

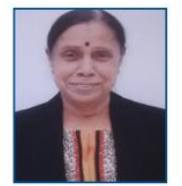

Dr. K. Savithri

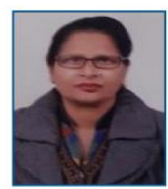

Dr. Bimla Ran

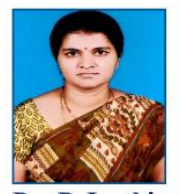

Dr. D Jyothi

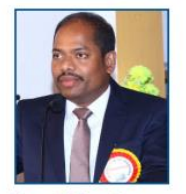

Dr. Mayilvaganan V

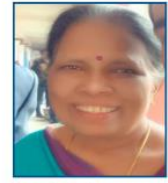

Dr. Rukumani

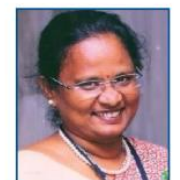

Dr. Maria Therese

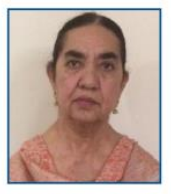

Dr. Amarjit Kaur Sandhu

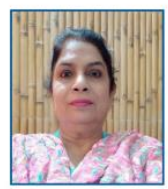

Dr. Harvinder Kaur

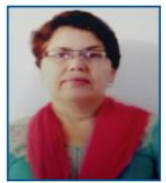

Dr. Prabha Kashyap

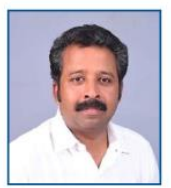

Dr. M.K. Franklin Shaju

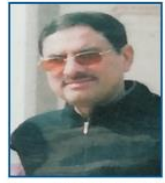

Dr. GM Malik

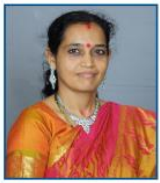

Dr. Manjubala Dash

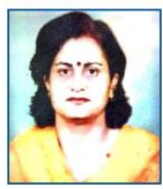

Dr. Krishna Chauhan

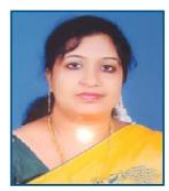

Dr. S.S. Sharmila Jansi Rani

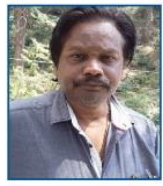

Mr. Dilip Jain

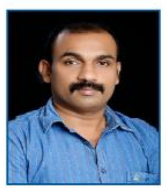

Dr. R.T.J.R. Lodline

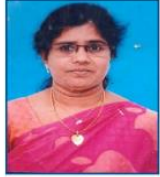

Dr. Shanthi Appavu

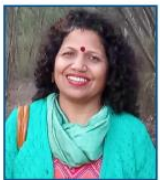

Dr. Shama Lohumi

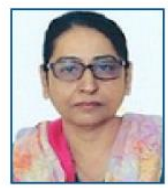

Dr. Parampal Kaur Cheema

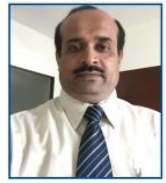

Dr. Rajesh G Konnur

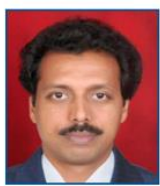

Dr. Nandprakash P.

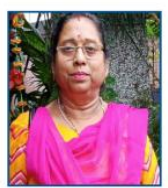

Dr. Venu Lata Saxena

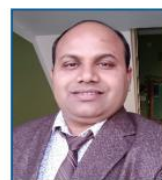

Dr. Khemchano

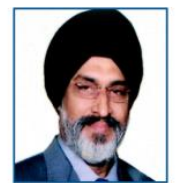

Dr. Ishwer Singh

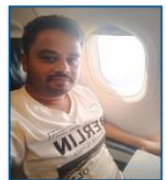

Mr. Sathish Kumar

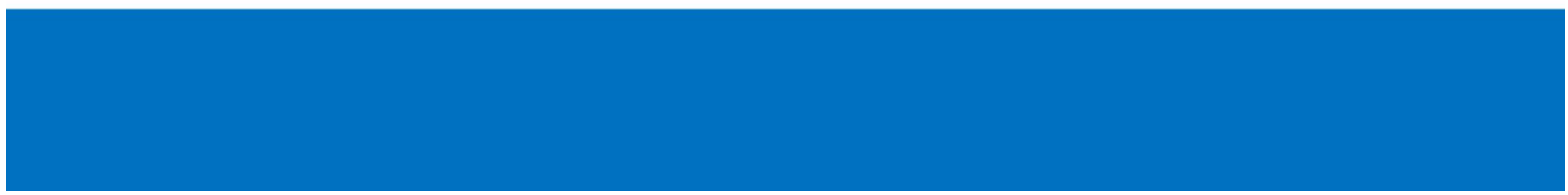




\section{MULTIDISCIPLINARY E-PAPER WORKSHOP - ABSTRACTS}

ISBN 978-81-946804-0-6

DOI: http://doi.org/10.472111/book.2020.9788194680406

\begin{tabular}{|c|c|c|c|}
\hline S. NO. & AUTHOR & TITLE & $\begin{array}{l}\text { PAGE } \\
\text { NUMBER }\end{array}$ \\
\hline 1 & $\begin{array}{l}\text { Mrs. Bhawna Gupta, } \\
\text { Dr. Amandeep Kaur }\end{array}$ & $\begin{array}{c}\text { EFFECTIVENESS OF PROGRESSIVE MUSCLE RELAXATION } \\
\text { TECHNIQUE ON PHYSICAL SYMPTOMS AMONG PATIENTS } \\
\text { RECEIVING CHEMOTHERAPY }\end{array}$ & 6 \\
\hline 2 & Dr. Vinoli. S. G & $\begin{array}{c}\text { EVALUATE THE EFFECTIVENESS OF WORKPLACE PHYSICAL } \\
\text { EXERCISE PROGRAMME ON MUSCULOSKELETAL PAIN AND } \\
\text { FUNCTIONAL LIMITATION AMONG SEDENTARY OFFICE } \\
\text { WORKERS }\end{array}$ & 7 \\
\hline 3 & Dr. Harvinder Kaur & $\begin{array}{c}\text { ASSESS THE EFFECTIVENESS OF STRUCTURED TEACHING } \\
\text { PROGRAMME ON KNOWLEDGE AND PRACTICE REGARDING } \\
\text { MANAGEMENT OF ARRHYTHMIAS }\end{array}$ & 8 \\
\hline 4 & $\begin{array}{l}\text { Mrs. G. Brindha } \\
\text { Mary, } \\
\text { Dr. S. S. Sharmila } \\
\quad \text { Jansi Rani }\end{array}$ & $\begin{array}{l}\text { EFFECTIVENESS OF AWARENESS PROGRAM ON KNOWLEDGE } \\
\text { REGARDING ORGAN DONATION AMONG ADOLESCENTS }\end{array}$ & 9 \\
\hline 5 & Mrs. Jyoti Kapoor & $\begin{array}{c}\text { ASSESSMENT OF THE KNOWLEDGE, ATTITUDE AND PRACTICES } \\
\text { REGARDING COVID-19 AMONG STUDENTS IN GOVERNMENT } \\
\text { PARAMEDICAL INSTITUTE, JAMMU (J\&K) }\end{array}$ & 10 \\
\hline 6 & Dr. Induja. S & $\begin{array}{c}\text { A QUASI EXPERIMENTAL STUDY TO EVALUATE THE } \\
\text { EFFECTIVENESS OF SELF ENHANCEMENT PROGRAMME ON } \\
\text { SELF-ESTEEM AND DEPRESSION AMONG INSTITUTIONALIZED } \\
\text { ELDERS IN SELECTED GERIATRIC HOMES AT MADURAI }\end{array}$ & 11 \\
\hline 7 & Ms. Urmal & $\begin{array}{l}\text { LIFESTYLE CHANGES TO MANAGE CORONARY ARTERY DISEASE } \\
\text { (CAD) }\end{array}$ & 12 \\
\hline 8 & $\begin{array}{l}\text { Dr. Rajendra Prasad } \\
\text { Sharma }\end{array}$ & $\begin{array}{l}\text { A COMPARATIVE STUDY TO ASSESS MENTAL HEALTH STATUS } \\
\text { AMONG THE PROFESSIONAL \& NONPROFESSIONAL } \\
\text { STUDENTS IN SELECTED COLLEGES OF JAIPUR CITY }\end{array}$ & 13 \\
\hline 9 & $\begin{array}{l}\text { Ms. Renjini. T, } \\
\text { Dr. Shaifali Rachna } \\
\text { Puri }\end{array}$ & $\begin{array}{c}\text { ENGLISH LANGUAGE LEARNING: CHALLENGES AND STRATEGIES } \\
\text { FOR YOUNG LEARNERS }\end{array}$ & 14 \\
\hline 10 & Dr. Laxmi Rana & SCIENTIFIC MISCONDUCTS & 15 \\
\hline 11 & $\begin{array}{l}\text { Ms. Arti Devi, } \\
\text { Dr. Amandeep Kaur }\end{array}$ & $\begin{array}{l}\text { CAREGIVER BURDEN FOR CAREGIVERS OF DEPENDENT } \\
\text { PATIENTS: A SYSTEMATIC REVIEW }\end{array}$ & 16 \\
\hline 12 & $\begin{array}{l}\text { Mrs. Rufina S } \\
\text { Johnson }\end{array}$ & $\begin{array}{c}\text { A STUDY TO FIND OUT THE PREVALENCE AND ASSESS THE } \\
\text { EFFECTIVENESS OF STRUCTURED TEACHING PROGRAM AMONG } \\
\text { ANTENATAL MOTHERS WITH ANEMIA AT TERTIARY CARE } \\
\text { HOSPITAL KUPPAM, A.P }\end{array}$ & 17 \\
\hline 13 & Mrs. Kuldish Kaur & BREAST SELF EXAMINATION FOR BREAST AWARENESS & 18 \\
\hline 14 & $\begin{array}{l}\text { Mr. Aneel Kumar } \\
\text { Dugga, } \\
\text { Dr. Aamarpali Roy }\end{array}$ & HOW TO LIVE PLASTIC FREE LIFE? & 19 \\
\hline 15 & $\begin{array}{l}\text { Mrs. Anuradha } \\
\text { Panda }\end{array}$ & $\begin{array}{l}\text { A STUDY TO ASSESS THE KNOWLEDGE REGARDING WARNING } \\
\text { SIGNS OF PREGNANCY AMONG PRIMIGRAVID MOTHERS IN } \\
\text { SELECTED HOSPITAL, ODISHA WITH A VIEW TO DEVELOP A SELF- } \\
\text { INSTRUCTIONAL MODULE }\end{array}$ & 20 \\
\hline 16 & Dr. Sathia Sweetly S & IMPACT OF COVID - 19 AMONG CHILDREN & 21 \\
\hline 17 & Ms. Delisha A. S & $\begin{array}{l}\text { WATER POLLUTION IN AVM CANAL: KNOWLEDGE AND } \\
\text { ATTITUDE OF RESIDENTS }\end{array}$ & 22 \\
\hline 18 & $\begin{array}{l}\text { Dr. Mandeep Kaur, } \\
\text { Ms. Navneet Kaur, } \\
\text { Ms. Prabhjot Kaur }\end{array}$ & KNOWLEDGE REGARDING DENGUE FEVER AMONG ADULTS & 23 \\
\hline
\end{tabular}




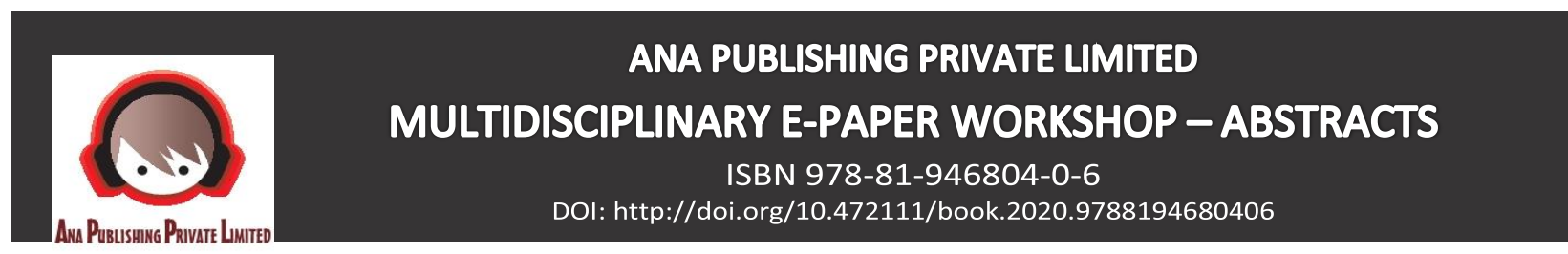

\begin{tabular}{|c|c|c|c|}
\hline S. NO. & AUTHOR & TITLE & $\begin{array}{c}\text { PAGE } \\
\text { NUMBER }\end{array}$ \\
\hline 19 & $\begin{array}{l}\text { Mrs. Sheela Rajeev } \\
\text { Tiwari }\end{array}$ & $\begin{array}{l}\text { A STUDY TO ASSESS THE EFFECT OF STRUCTURED } \\
\text { TEACHING PROGRAMME RELATED TO IMPORTANCE OF } \\
\text { ORGAN DONATION AMONG ADULTS OF LUCKNOW CITY }\end{array}$ & 24 \\
\hline 20 & $\begin{array}{l}\text { Ms. Romy Khurana, } \\
\text { Dr. Shaifali Rachna Puri }\end{array}$ & $\begin{array}{l}\text { CHALLENGES IN LEARNING AND TEACHING SECOND } \\
\text { LANGUAGE }\end{array}$ & 25 \\
\hline 21 & Dr. Ashok Dhanwal & $\begin{array}{c}\text { ASSESSMENT OF KNOWLEDGE AND ATTITUDE OF } \\
\text { PARENTS REGARDING UNIVERSAL IMMUNIZATION } \\
\text { PROGRAMME (UIP) }\end{array}$ & 26 \\
\hline 22 & $\begin{array}{l}\text { Mr. Praveen L } \\
\text { Subravgoudar }\end{array}$ & $\begin{array}{c}\text { A STUDY TO ASSESS THE SELF-ESTEEM \& ATTITUDE } \\
\text { TOWARDS NURSING PROFESSION AMONG FINAL YEAR } \\
\text { NURSING STUDENTS STUDYING IN D. Y. PATIL COLLEGE OF } \\
\text { NURSING, KOLHAPUR }\end{array}$ & 27 \\
\hline 23 & $\begin{array}{l}\text { Dr. M. B. Aruna } \\
\text { Arputhamalar }\end{array}$ & $\begin{array}{c}\text { EFFECTIVENESS OF STRUCTURED TEACHING PROGRAMME } \\
\text { ON SEX AWARENESS AMONG ADOLESCENT GIRLS }\end{array}$ & 28 \\
\hline 24 & $\begin{array}{c}\text { Ms. Chitra Sharma, } \\
\text { Dr. Shaifali Rachna Puri }\end{array}$ & $\begin{array}{c}\text { THE IMPACT OF SOCIO-ECONOMIC STATUS ON LEARNING } \\
\text { ENGLISH AMONG CHILDREN OF KAMRUP, INDIA }\end{array}$ & 29 \\
\hline 25 & $\begin{array}{l}\text { Dr. Seema Chauhan, } \\
\text { Dr. Shama Lohumi }\end{array}$ & $\begin{array}{c}\text { EVALUATING THE KNOWLEDGE, PERCEPTION AND } \\
\text { ATTITUDE OF STUDENTS OF GOVERNMENT SCHOOLS } \\
\text { TOWARDS HIV/AIDS IN SHIMLA }\end{array}$ & 30 \\
\hline 26 & $\begin{array}{l}\text { Dr. Arundeep Kaur, } \\
\text { Mrs. Jasdeep Kaur, } \\
\text { Ms. Harmanpreet Kaur, } \\
\text { Ms. Jyoti Sharma }\end{array}$ & $\begin{array}{l}\text { KNOWLEDGE REGARDING DIARRHEA AND ORS } \\
\text { PREPARATION AMONG POSTNATAL MOTHERS }\end{array}$ & 31 \\
\hline 27 & Mr. Kodeeswaran A & $\begin{array}{c}\text { A STUDY TO ASSESS THE EFFECTIVENESS OF } \\
\text { BIBLIOTHERAPY ON STRESS AMONG CANCER PATIENTS IN } \\
\text { SELECTED CANCER HOSPITALS, AT ERODE DISTRICT }\end{array}$ & 32 \\
\hline 28 & Ms. Komala. H. K & $\begin{array}{c}\text { A STUDY TO EVALUATE THE EFFECTIVENESS OF } \\
\text { STRUCTURED TEACHING PROGRAMME (STP) ON } \\
\text { KNOWLEDGE REGARDING WIFS PROGRAMME AMONG } \\
\text { ADOLESCENTS }\end{array}$ & 33 \\
\hline 29 & Mrs. Jasintha. S & $\begin{array}{c}\text { IMPACT OF SMARTPHONE ADDICTION ON SOCIAL AND } \\
\text { EDUCATIONAL LIFE OF ADOLESCENTS }\end{array}$ & 34 \\
\hline 30 & Mrs. Paramjit Kaur & $\begin{array}{l}\text { TO ASSESS KNOWLEDGE AND ATTITUDE REGARDING } \\
\text { GENETIC COUNSELLING AMONG MARRIED WOMEN IN } \\
\text { SELECTED AREAS }\end{array}$ & 35 \\
\hline 31 & $\begin{array}{l}\text { Mrs. Savithri K. B., } \\
\text { Dr. Raj Rani }\end{array}$ & $\begin{array}{c}\text { ASSESSMENT OF RISK FACTORS AND QUALITY OF LIFE } \\
\text { AMONG NURSES WITH VARICOSE VEINS AT TERTIARY } \\
\text { HEALTH CARE HOSPITALS, CHENNAI }\end{array}$ & 36 \\
\hline 32 & $\begin{array}{l}\text { Mr. Jibin Varghese } \\
\text { Dr. Amandeep Kaur }\end{array}$ & $\begin{array}{c}\text { MENTAL HEALTH PROMOTION AND EARLY } \\
\text { IDENTIFICATION OF MENTAL ILLNESS AMONG } \\
\text { ADOLESCENTS }\end{array}$ & 37 \\
\hline 33 & Ms. Urmal & STAYING HEALTHY AT MENOPAUSE AND BEYOND & 38 \\
\hline 34 & Dr. Harleen Kaur & $\begin{array}{c}\text { A DESCRIPTIVE STUDY TO ASSESS THE KNOWLEDGE } \\
\text { REGARDING DENTAL CARE AMONG THE STUDENTS OF } \\
\text { GOVERNMENT ELEMENTARY SCHOOL AT MUDHAL, } \\
\text { AMRITSAR WITH A VIEW TO PREPARE INFORMATION } \\
\text { GUIDE SHEET }\end{array}$ & 39 \\
\hline 35 & Ms. G. Karpagavalli & $\begin{array}{c}\text { STUDY ON IMPACTS AND MANAGEMENT OF PMS } \\
\text { AMONG ADOLESCENT GIRLS IN SELECTED SCHOOL AT } \\
\text { CHENNAI }\end{array}$ & 40 \\
\hline
\end{tabular}




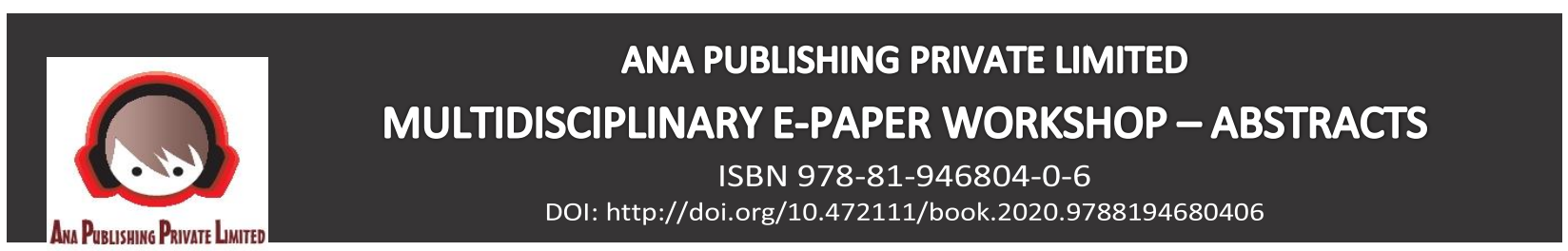

\title{
ABSTRACT. 1 \\ EFFECTIVENESS OF PROGRESSIVE MUSCLE RELAXATION TECHNIQUE ON PHYSICAL SYMPTOMS AMONG PATIENTS RECEIVING CHEMOTHERAPY
}

\author{
Mrs. Bhawna Gupta*| Dr. Amandeep Kaur** \\ *Assistant Professor, Khalsa College of Nursing, Amritsar, Punjab, India. \\ **Executive Editor, Ana Publishing Private Limited, India.
}

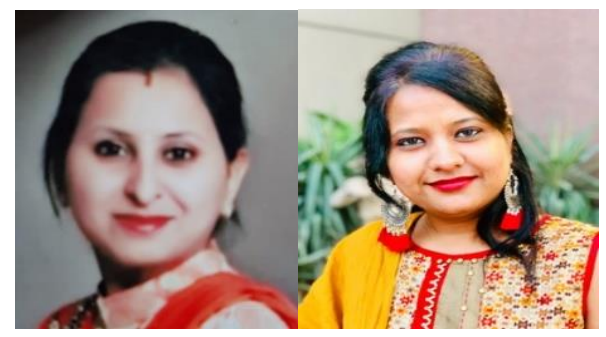

Mrs. Bhawna Gupta | Dr. Amandeep Kaur

\begin{abstract}
Cancer is second in all the leading causes of morbidity and mortality worldwide, with more or less $13 \%$ in total deaths worldwide in 2018. Total deaths due to cancer in India was 7, 84,821 in 2018. Estimated number of people living with the disease is around 2.25 million and every year new cancer patients registered are 11 , 57294 lakh. The number of recent cases is predicted to rise by concerning seventieth over consequent a try of decades. Globally, nearly one in six deaths is because of cancer. The present study was used to assess the effectiveness of progressive muscle relaxation technique on physical symptoms among patients receiving chemotherapy. The data from a sample of 20 cancer patients receiving chemotherapy admitted in shri guru ramdass hospital of Amritsar, Punjab. 10 patients in experimental group and 10 patients in control group were selected using purposive sampling technique. The results of the study showed highly significant difference in pre-interventional and post-interventional physical symptoms of experimental and control group. The $Z$ value (Wilcoxon signed rank test) between pre-intervention and post-intervention in experimental group related to nausea was 2.897 which were found statistically significant at $p<0.05$. The $Z$ value between pre-intervention and post-intervention in control group related to nausea was 1.000 which was found statistically nonsignificant in control group at $p>0.05$. Hence, it was concluded that in control group physical symptoms were not relieved. The $Z$ value between pre-intervention and post-intervention in experimental group in experimental group related to vomiting was 2.879 which were found highly significant at $p<0.05$. Hence, it was concluded that progressive muscle relaxation technique has significant effect in relieving physical symptoms. The $Z$ value between pre-intervention and post-intervention in control group related to vomiting was 1.000 which was found non-significant at $p<0.05$. Hence, it was concluded that in control group physical symptoms were not relieved. The $Z$ value between pre-intervention and post-intervention in experimental group related to pain was 2.899 which was found highly significant at $p<0.05$. The $Z$ value between preintervention and post-intervention in control group related to pain was 0 which was found non-significant at $p<0.05$. Hence, it was concluded that progressive muscle relaxation technique has significant effect in relieving physical symptoms.
\end{abstract}

Key Words: Effectiveness, Progressive Muscle Relaxation Technique, Physical Symptoms, Cancer patients, Chemotherapy, Wilcoxon-signed rank test. 


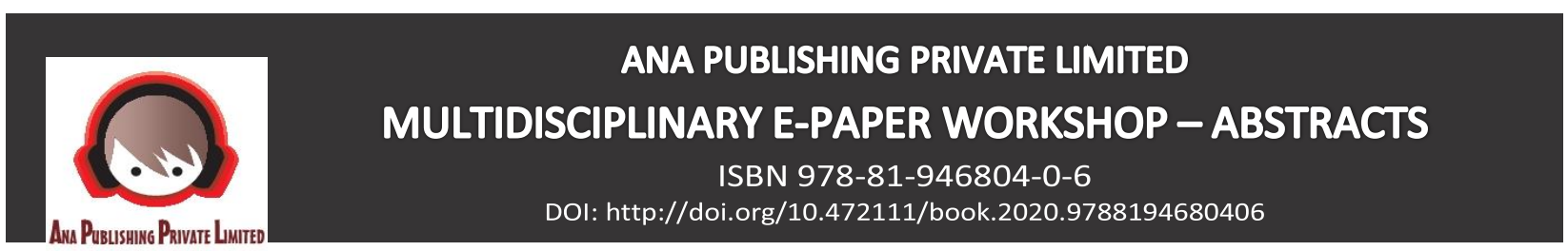

\title{
ABSTRACT. 2 \\ EVALUATE THE EFFECTIVENESS OF WORKPLACE PHYSICAL EXERCISE PROGRAMME ON MUSCULOSKELETAL PAIN AND FUNCTIONAL LIMITATION AMONG SEDENTARY OFFICE WORKERS
}

\author{
Dr. Vinoli. S. G
}

Professor, Universal College Of Nursing, Bangalore, Karnataka, India.

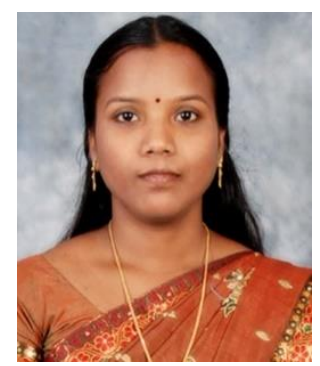

\section{ABSTRACT}

Dr. Vinoli. S. G

Computer based customer service work is one of the most rapidly growing occupations in the world. In the coming years, postural or musculoskeletal problems will be common to many sedentary job employees. To evaluate the effectiveness of workplace physical exercise programme on musculoskeletal pain and functional limitations among the sedentary office workers, a True experimental pre-test post-test design with control group was adopted. 200 sedentary office workers were selected by simple random sampling method. Pre-test was done by using self-administered questionnaire. After the pre-test teaching and demonstration was given to the experimental group. Once in every 15 days the samples were supervised for their performance. Totally six observations were made for each sample throughout the study. After completion of six observations the post-test was conducted. The results showed that there was a significant difference between the pre-test and post-test mean musculoskeletal pain score $(t=40.168, \mathrm{P}=0.000)$ in the experimental group. There was a significant difference in the post-test mean musculoskeletal pain score between the experimental and control group $(t=13.738, P=0.000)$. It also exhibits that there was a significant difference between the pre-test and post-test mean functional limitations score $(t=30.709, P=0.000)$ in the experimental group. There was a significant difference in the post-test mean functional limitations score between the experimental and the control group $(\mathrm{t}=18.3, \mathrm{P}=0.000)$. There was a highly significant relationship between musculoskeletal pain and functional limitations in both the experimental group and the control group during pre-test and post-test. So it was inferred that workplace physical exercise programme was highly effective in reducing work related musculoskeletal pain and improve the functional abilities.

Key Words: Sedentary office workers, musculoskeletal pain and functional limitations. 


\section{ABSTRACT. 3 \\ ASSESS THE EFFECTIVENESS OF STRUCTURED TEACHING PROGRAMME ON KNOWLEDGE AND PRACTICE REGARDING MANAGEMENT OF ARRHYTHMIAS}

Dr. Harvinder Kaur

Principal, Guru Nanak College of Nursing, Gopalpur, Ludhiana, Punjab, India.

\section{ABSTRACT:}

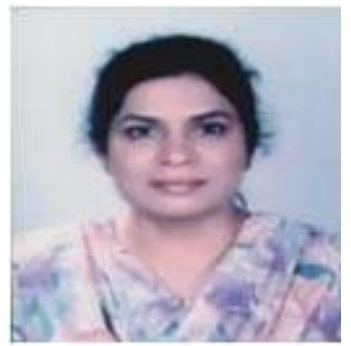

\section{Dr. Harvinder Kaur}

There are several technical advancements in assessing and interpreting cardiac arrhythmia. The nurses play a vital role to take necessary and immediate action to correct them at right time. Since nurses cares for their patients around the clock and need to higher the level of knowledge and skill in interpretation and initiating step to the management of arrhythmia, hence a study was conducted to assess the effectiveness of structured teaching programme on knowledge and practice regarding management of arrhythmias among staff nurses. Objective of the study to: Determine and assess the effectiveness of structured teaching programme on knowledge and Correlate the level of knowledge with practice regarding management of arrhythmias and associate the level of knowledge and practice with selected demographic variables. Methodology: A Quasiexperimental research approach is adopted for the study. A total of 200 staff nurses were selected, 100 were experimental group and 100 were in control group. Sample was selected by using Non- probability convenience sampling technique who met the inclusion and exclusion criteria. A structured 30 knowledge and 10 practice questionnaire regarding management of arrhythmias was prepared and utilized as data collection tool to collect the data from the samples. A structured teaching programme on knowledge and practice regarding management of arrhythmias was given as intervention for the experimental group. Data were analysed using descriptive and inferential statistics. Results: In comparison of overall mean percentage of posttest knowledge score in experimental group is highly significant with paired $\mathrm{t}^{\prime}=5.72$, at $\mathrm{p}<0.001^{* * *}$, control group is NS with paired $\mathrm{t}^{\prime}=0.3$, at $\mathrm{p}>0.05$ and in comparison of both group, pre-test paired $\mathrm{t}^{\prime}=0.92$, at $\mathrm{p}>0.05=\mathrm{NS}$ and post-test paired $\mathrm{t}^{\prime}=7.05$, at $\mathrm{p}<0.001^{* * *}=$ highly significant. Overall mean percentage of posttest practice score in experimental group is highly significant with paired ${ }^{\prime} t^{\prime}=5.20$, at $p<0.001^{* * *}$. In post-test practice score of control group is NS significant with paired ${ }^{\prime} t^{\prime}=1.29$, at $p>0.05$ and in comparison of both group, pre-test paired ${ }^{\prime} t^{\prime}=2.69$, at $\mathrm{p}<0.001^{* *}=$ significant at $1 \%$ level and post-test paired $\mathrm{t}^{\prime}=7.42$, at $\mathrm{p}<0.001^{* * *}=$ highly significant. CONCLUSIONS: There is a positive correlation between pre-test knowledge and practice scores. Thus STP is effective in improving knowledge and practice of staff nurses regarding management of arrhythmias.

Key Words: Knowledge and practice of staff nurses, management of arrhythmias, structured teaching programme. 


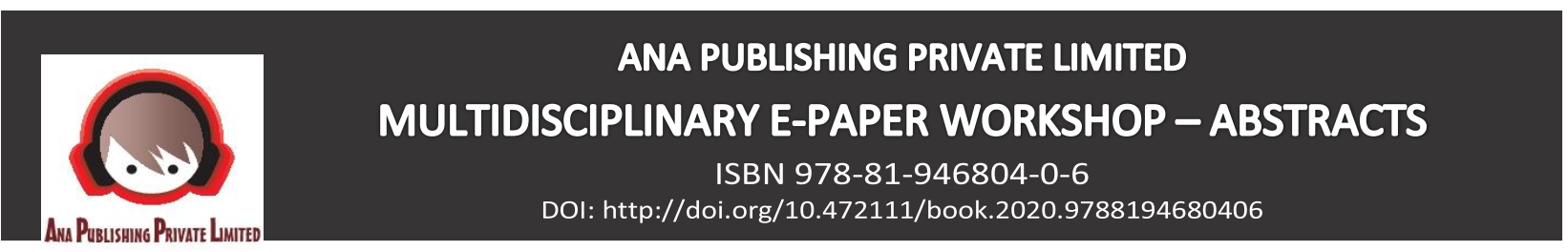

\section{ABSTRACT. 4 \\ EFFECTIVENESS OF AWARENESS PROGRAM ON KNOWLEDGE REGARDING ORGAN DONATION AMONG ADOLESCENTS}

\section{Mrs. G. Brindha Mary ${ }^{*}$ | Dr. S. S. Sharmila Jansi Rani**}

*Assistant Professor, Thasiah College of Nursing, Marthandam, Tamil Nadu, India.

**Vice Principal, Christian College of Nursing, Neyyoor, Tamil Nadu, India.

\section{ABSTRACT}

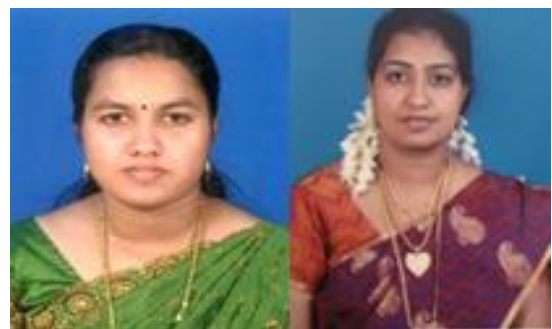

Mrs. G. Brindha Mary | Dr. S. S. Sharmila Jansi Rani

Organ donor is a real hero. One organ and tissue donor has the potential to save and enhance more than 50 lives. The aim of the study is to evaluate the effectiveness of awareness program on organ donation among adolescents in selected schools at Kanyakumari district. The research design adopted for this study is pre experimental one group pre-test post-test design. Simple random sampling technique was used to select the samples. The conceptual frame work of this study is based on King's Goal Attainment theory. The data was collected from 60 adolescents in selected schools at Kanyakumari district by using structured knowledge questionnaire regarding organ donation. Pre-test was conducted to the adolescents by using structured knowledge questionnaire on organ donation. On the same day awareness program was given by the investigator. After seven days of awareness program post test was conducted to the adolescents by using same structured knowledge questionnaire. The pre-test mean value was 13.61 with standard deviation of 2.04 where as in post-test mean value was 24.92 with standard deviation of 3.42. The mean difference was 11.31 . It shows that there was increase in the post-test knowledge score. The Paired' $t$ ' value was 39.32 which is higher than the table value and was significant and it shows there was effectiveness of awareness programme. The association between the knowledge and selected demographic variables, some of the factors were having association with the selected demographic variables were significant at $P<0.001$. Significance which shows that research hypothesis is partially accepted and partially rejected.

Key Words: Awareness program, organ donation, transplantation. 


\section{ANA PUBLISHING PRIVATE LIMITED \\ MULTIDISCIPLINARY E-PAPER WORKSHOP - ABSTRACTS \\ ISBN 978-81-946804-0-6 \\ DOI: http://doi.org/10.472111/book.2020.9788194680406}

\section{ABSTRACT. 5 \\ ASSESSMENT OF THE KNOWLEDGE, ATTITUDE AND PRACTICES REGARDING COVID-19 AMONG STUDENTS IN GOVERNMENT PARAMEDICAL INSTITUTE, JAMMU (J\&K) \\ Mrs. Jyoti Kapoor \\ Tutor, Government College of Nursing, Gangyal, Jammu, India.}

\section{ABSTRACT:}

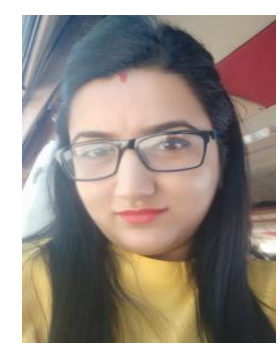

Mrs. Jyoti Kapoor

The novel corona virus disease 2019 (COVID-19) caused by severe acute respiratory syndrome corona virus 2 (SARS-CoV-2) was initially diagnosed from Wuhan, Hubei Province (Mainland China), has already taken on pandemic proportions and global health issue, affected the whole world in a very short span of time. Objective: The present study was under taken to assess the knowledge, attitude and practices regarding COVID-19 among paramedical students in Govt. AMT School, Jammu (J\&K). Methods: The sample consisted of 120 paramedical students of GNM and D pharmacy. Socio-demographic profiles, a self-structured questionnaire exhibiting knowledge, attitude and practice questions, were used to collect the data from subjects. Results: The results revealed that during the covid-19 pandemic, $72.5 \%$ of the participants had very good knowledge of COVID-19. In addition, more than $65 \%$ of the participants had a positive attitude towards COVID-19 and $81.6 \%$ had satisfactory practices regarding COVID-19.Conclusion: Thus, the study concluded that most of the students had good knowledge, positive attitude and reliable practices towards COVID-19 during the pandemic but still there is need to be more aware about this pandemic and safety measures so that we all can win the battle against this virus.

Keywords: COVID-19, Knowledge, Attitude, Practices. 
ABSTRACT. 6

A QUASI EXPERIMENTAL STUDY TO EVALUATE THE EFFECTIVENESS OF SELF ENHANCEMENT PROGRAMME ON SELF-ESTEEM AND DEPRESSION AMONG INSTITUTIONALIZED ELDERS IN SELECTED GERIATRIC HOMES AT MADURAI

Dr. Induja. S

Professor, Velammal School and college of Nursing, Anupannadi, Tuticorin ring Road, Madurai, India.

ABSTRACT:

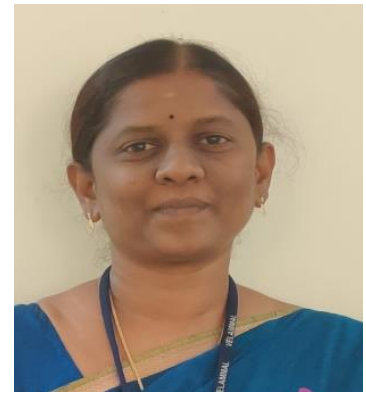

Dr. Induja. S

Aging comes with a new set of issues. Many people are aware of the physical challenges that can come with aging: less flexibility, loss of fitness and an increase in disease. Being alone can be extremely unpleasant any age. It's something that many people fear about growing old because unfortunately social isolation is common amongst the elderly. The aim of the study is to assess the effectiveness of self enhancement program on self-esteem and depression among the institutionalized elderly in old age homes. Quasi experimental pre-test-post-test control group design was used for the study. The study was conducted in selected five old age homes in Madurai. A total of 200 samples elderly were selected using convenience sampling technique. Among 200, 100 were in the experimental group and 100 were in the control group. Tools used were Rosenberg self-esteem scale and Beck depression inventory was administered over 2 days in a week for 7 consecutive weeks. Data were analysed using descriptive and inferential statistics. Results: the self enhancement program was effective in improving self-esteem post-test $1(F=543.243, p<0.001)$, post-test I against post-test II $(F=544.849, p, 0.001)$ and post-test II against post-test III $(f=644.454$, $\mathrm{p}<0.001$ ) of the experimental group. Geriatric psychology looks at the mental health issue of people over the age of 65. Many of us often feel unpleasant to grow older. Our society and culture also value only youth and treat getting old as a disease that has no cure. Retirement, Ageism and social isolation are identified as three main challenges of aging. Encaging in self-enhanced activities in daily life will reduce the possibilities of increasing self- esteem.

Key Words: Institutionalized elderly, self-esteem, depression, self enhancement program. 


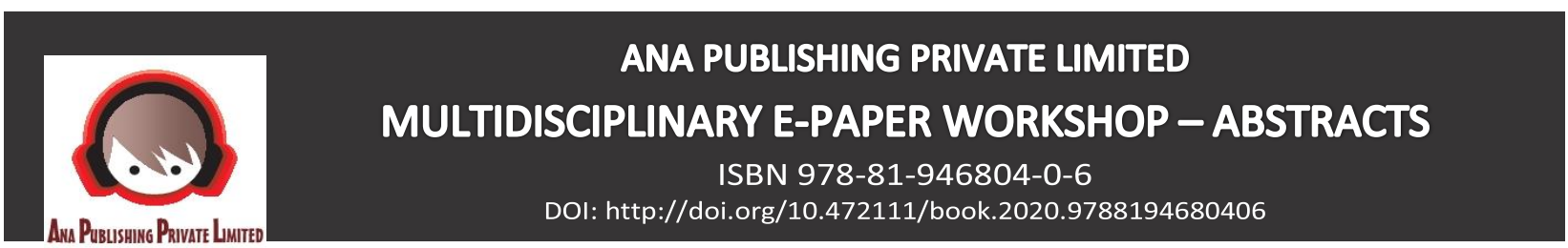

\section{ABSTRACT. 7 \\ LIFESTYLE CHANGES TO MANAGE CORONARY ARTERY DISEASE (CAD)}

Ms. Urmal

Tutor, Department of Medical Surgical Nursing, Government Nursing College, Rajindra Hospital, Patiala, Punjab, India.

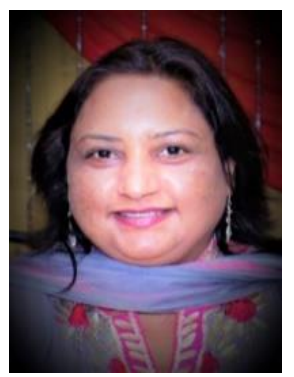

Ms. Urmal

\section{ABSTRACT}

Coronary artery disease (CAD) is one of the major cardiovascular diseases affecting the global human population. This disease has been proved to be the major cause of death in both the developed and developing countries. Lifestyle, environmental factors, and genetic factors pose as risk factors for the development of cardiovascular disease. In Coronary Artery Disease (CAD), the coronary arteries supply blood to the heart muscle. CAD is damage or disease of these arteries. These changes slow or stop the flow of blood. Ischemia-damage to heart tissue. Angina-Chest pain caused by slowed blood flow to the heart. For some this may feel like a pressure or even shortness of breath. Heart disease risk factors that cannot change Age: Men age 45 and older and women age 55 and older have a greater risk. Gender: Estrogen provides women some protection against heart disease, but diabetes raises the risk of heart disease more in women than in men. Race or ethnicity: African Americans are more likely than whites to have heart disease, while Hispanic Americans are less likely to have it, Family history. Greater risk if you have a close family member who had heart disease at an early age. Things to lower risk of heart disease Control your blood pressure. High blood pressure is a major risk factor for heart disease. It is important to get blood pressure checked regularly. Keep your cholesterol and triglyceride levels under control. Stay at a healthy weight. Eat a healthy diet Get regular exercise. Limit alcohol. Don't smoke. Manage stress Manage diabetes. Enough sleep. Conclusion: Lifestyle changes, including regular exercise, following a heart-healthy diet, quitting smoking and avoiding second-hand smoke, and addressing depression and other psychosocial modulators of behaviour, provide independent and additive benefits to patients with CVD.

Key Words: Coronary Artery Disease, Life style, Heart. 


\section{ABSTRACT. 8 \\ A COMPARATIVE STUDY TO ASSESS MENTAL HEALTH STATUS AMONG THE PROFESSIONAL \& NONPROFESSIONAL STUDENTS IN SELECTED COLLEGES OF JAIPUR CITY}

Dr. Rajendra Prasad Sharma

Associate Professor, Mahatma Gandhi Nursing College, Sitapura-Jaipur, Rajasthan, India.

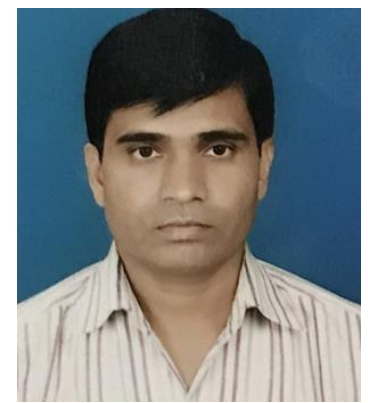

\section{ABSTRACT}

Dr. Rajendra Prasad Sharma

Mental health means not only being free from mental illness, but also the adjustment of an individual's to themselves and the world at large with maximum or effectiveness, satisfaction, cheerfulness, and social considerate behaviour and the ability of facing and accepting the realities of life. Nursing is a stressful profession that deals with intense human aspects of health and IIness. Consequently, the stressful nature of nursing can ultimately lead to dissatisfaction. College students are the cream of young population, \& are at high risk for having Psychological problems because of nature of their work. Many students are away from home \&learn with little guidance as to how to manage their own affairs and become adjusted to new Conditions. Some find the transition from a rural to an urban way of life upsetting and one anxious in their new surroundings. The stress related to with study, financial difficulties, and anxiety about examinations and future career result in college students suffering from recognizable mental disorders like anxiety, depression, personality disorder and these mental disorders associated with poor academic performance, irregularity in the classes, dropping out of the course, unusual and unwanted behaviour, aggression, alcohol and drug abuse suicide etc. From the economic point of view students represent an investment of capital by nation and failure by students in their final examination represents a loss of return of this investment. Methods The research design used for the study was Non-Experimental Research Design. The study was conducted among professional and non-professional students at Jaipur city. The study was conducted from 01/03/2014 to 30/03/2014. A sample size of 120 students was selected through non-probability purposive sampling technique. 120 students were selected to participate in the study. After obtaining the written consent from students for willingness to participate in the study, a demographic data sheet was given to the students, followed by mental health status were administered to the students to assess the level of mental health. The data were analyzed and interpreted in terms of objectives formulated. The cooperative and inferential statistics were used in data analysis. The result of the study showed there is a significant association between the level of professional and non-professional, mental health and selected socio-demographic variables of students. This research reveals that there was a significant association between professional and nonprofessional, mental health status among students with demographic variables. A regular programme and instructions may be implemented for the students to improve the mental health. Mental health aspect to promote mental health nursing curriculum. There for health educators in various health settings can utilize it. It stress that there is a need of education program based on the level of professional and non-professional students. More continuing education training is needed for the students in this regard.

Key Words: Discrimination, Happiness, Safety and Security 


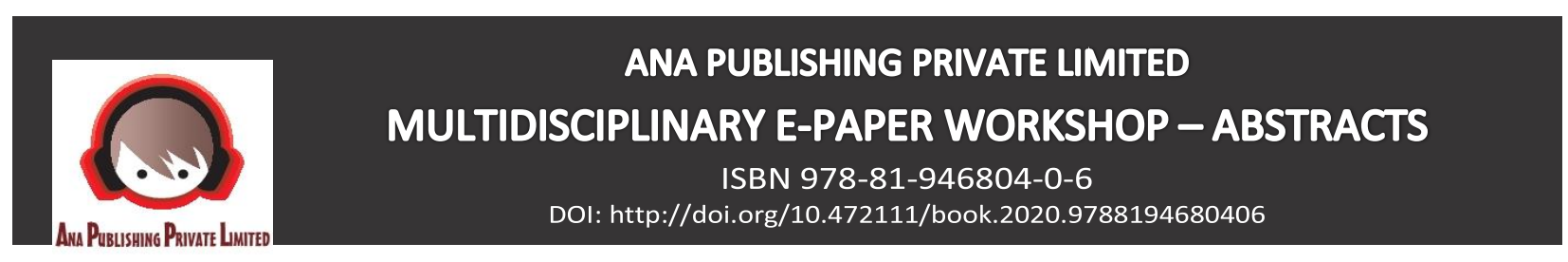

\title{
ABSTRACT. 9 \\ ENGLISH LANGUAGE LEARNING: CHALLENGES AND STRATEGIES FOR YOUNG LEARNERS
}

\author{
Ms. Renjini. ${ }^{*}$ | Dr. Shaifali Rachna Puri ${ }^{* *}$ \\ *Ph. D Scholar, Himalayan University, Arunachal Pradesh, India. \\ **Director, Ana Publishing Private Limited, India.
}

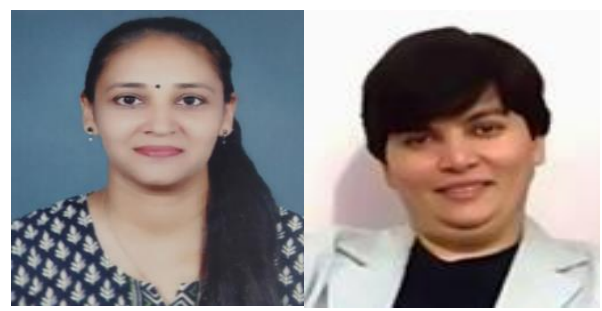

ABSTRACT:

Ms. Renjini. T | Dr. Shaifali Rachna Puri

In India, English is acknowledged as a language that enhances career prospects. It explains why demand for English education has increased among parents. However, the teaching and learning of English has been beset with bottlenecks, thus impacting learning outcomes in terms of developing English proficiency for practical purposes. Treating, teaching and learning English as a subject, rather than as a language, and its status as a 'library language' have been obstacles to the proper acquisition of language skills among students. While the problem exists for young learners at the school level, its impact is felt later in their lives, especially when they have to use English for practical purposes of higher learning or jobs. It is seen that the hype that goes with English education has not matched with learning outcomes, which is dismally below par. The inclusion of English merely as a language and a medium of instruction and then treating it as a subject to be learnt by rote only for exam scores have contributed to rendering the teaching-learning of English largely as a Sisyphean activity in terms of learning outcomes. What then are the challenges faced by young learners in learning English? Questionnaire-based data collected from students from English and vernacular (Marathi) medium schools reveals the following: 1) Most respondents say mother tongue influences their English 2) Most of them face difficulty when conversing with teachers in English 3) Most of them have bilingual (Marathi and English) mode of instruction Significantly, and despite the above factors, most respondents reported they enjoyed learning English, expressed overall satisfaction with regard to their English speaking ability, are aware of the purpose of learning English, feel they can prepare notes of their own, have individual and group activities in school to learn English, have their teachers using audio-visual aids and feel the vocabulary and structures they use in textbooks are useful in daily life. The above contradictions could be because of differences in students' perception - in urban, semi-urban and rural areas - of what 'good' and 'adequate' English is. However, the fact is that the level of English proficiency of respondents from rural or small town areas, such as the one surveyed for the present article, may not be sufficient in a scenario where they have to pursue higher education, or take up jobs. In this context, it will be opportune to evaluate how using home/local language, or mother tongue, as medium of instruction up to Grade 5, or even Grade 8, as per the new National Education Policy (NEP) will impact English language proficiency of students for practical purposes. Apparently, students who learn in the English medium up to the abovementioned grades are bound to enjoy the early starter advantage. My article proposes to consider all the above aspects.

Key Words: English, teaching, learning, language proficiency, NEP. 


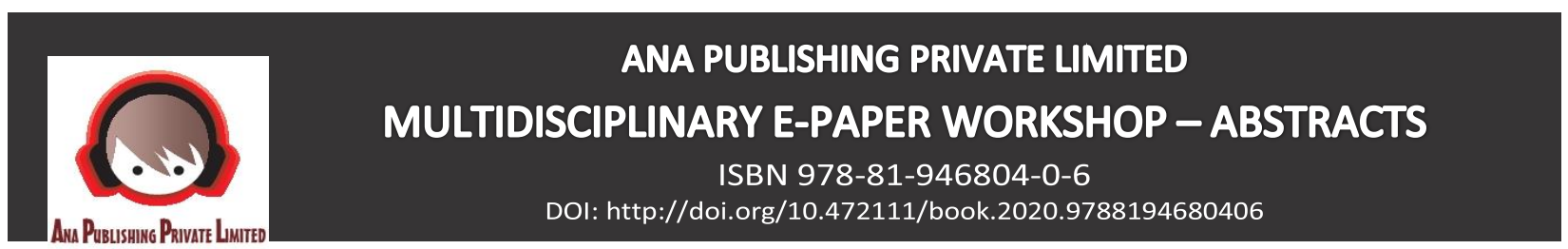

ABSTRACT. 10

\section{SCIENTIFIC MISCONDUCTS}

Dr Laxmi Rana

Research Guide, Himalayan University, Arunachal Pradesh, India.

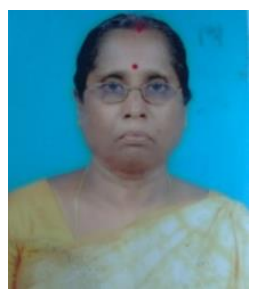

ABSTRACT:

Dr. Laxmi Rana

Conduct follows ethical principles based on policies in any scientific activity or investigation. When any one deliberately and repeatedly breaks the principles which affect the investigation process throughout or any part is called misconduct. Thus misconduct is an improper behaviour by a researcher if he violets the ethics of scientific research. Research is an undertaking intended to extend knowledge through a disciplined enquiry or scientific investigation. It aims at finding solution of problem through a systematic methodological scientific approach. The principles of research integrity are honesty, accountability, professional courtesy and good stewardship of research. Misconducts can be observed in data generation, data recording, and review of publication or dissemination of research report. Common research misconducts are fabrication, falsification, plagiarism and violation of authorship rules. Fabrication is intentionally Invention of data or cases by changing set up or results in an experimentation which cannot be justified .Falsification is intentionally destroying or alteration of observed result of an experimentation through manipulation of research materials, equipment's and processes or changing or omitting data or result. Plagiarism is most common and unethical practice where the researcher is coping someone else ideas and information as personal achievement without giving due recognition or credit to the actual source Further, violation of author ship rules is a major misconduct globally and increasing gradually. It includes deciding number or order of authors, ghost author, gift author, omitting actual author and using guide and co-guide as co-author. Factors related to research misconducts are academic or carrier pressure; publication pressure; reputation and recognition; financial gain; and poor understanding related to research and its publication. Outcome of scientific misconduct often results in loss of academic achievement, loss of research grants; loose the carrier, and even black listed. Prevention and control: Misconducts can be prevented through identification, elimination or minimizing risk factors, if monitored, investigated and reported promptly. Institutions must strictly follow policies and procedures to train, support and assist professionals. They must set standards and be vigilant to take action against misconducts. Plagiarism checker protects research copy right. And secure documents. Anti-plagiarism soft wires are Plagiarism checker soft wire or Apps available in India. Free detection tools such as, Plag scan are also available. Plagiarism up to $10 \%$ only is acceptable standard. Further, if more than one researcher decisions regarding authorship need to be discussed before conducting research .Indian Council of Medical Journal Editor guide lines to be followed. Highest involvement is given first priority and alphabetically to be written if contributions are same. Conclusions: Misconducts are unethical. There must be zero tolerance to these. It can be avoided or minimised if a clear plan developed and ethical review and agreement on authorship are decided before conducting research. During the process of investigation researcher need to work with approved protocol gaining consent, protecting self, team and participants as well as regularly checking data. After conducting research share the report following publication ethics and use reference management software. Lastly return something back to the researched community.

Key Words: Scientific misconduct, publication ethics, research ethics. 


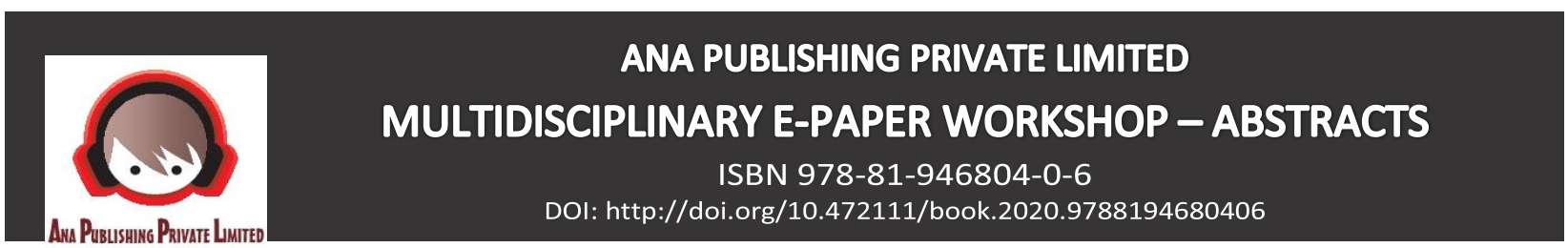

\section{ABSTRACT. 11 \\ CAREGIVER BURDEN FOR CAREGIVERS OF DEPENDENT PATIENTS: A SYSTEMATIC REVIEW}

Ms. Arti Devi*| Dr. Amandeep Kaur**

*Nursing Tutor, Shri Mata Vaishno Devi College of Nursing, Kakryal, Katra, Jammu, India.

**Executive Editor, Ana Publishing Private Limited, India.

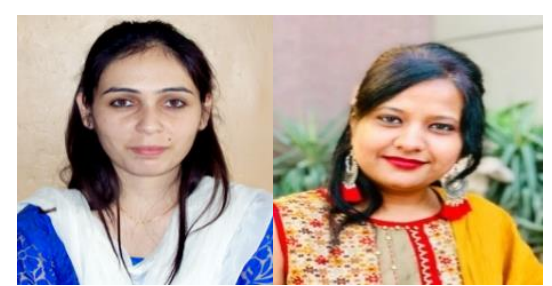

Ms. Arti Devi | Dr. Amandeep Kaur

\section{ABSTRACT:}

Caregiving in the circle of relatives is bounded through using normative gender unique expectancies of massive significance to Asian Indian families. A couple of position involvements can also result in inadequate allocation of sources, which consist of time, for the fulfilment of all of the roles the caregiver's play. This scarcity speculation focuses on the fee of a couple of function determination. In step with the lack hypothesis, people do now not have sufficient time and energy to fulfil a couple of feature responsibilities. Consequently, the multiplicity of roles produces characteristic overload. The researcher searched PubMed, CINAHL, Cochrane, Medline, and Google Scholar for identifying studies by using the various keywords, Boolean operators. The Research studies conducted after 2015 and published in national and international journals were selected. The data was extracted from different 13 research studies for secondary data analysis as per the inclusion and exclusion criteria and the data was extracted by including first author's name, publication year, subject / sample, setting, and research design of the study and main findings. The review and meta-analysis reveals that while the caregivers are providing the care to dependent patients, they perceive the physical, psychological, social burden. The review of the following studies shows that majority of the caregivers are providing the care to dependent patients and during that caregiving process they perceive the physical, psychological, social burden. Thus there is a need to take measures which can relieve the care givers burden.

Key Words: Caregivers burden, Systematic Review, Dependent patients. 


\title{
ABSTRACT. 12 \\ A STUDY TO FIND OUT THE PREVALENCE AND ASSESS THE EFFECTIVENESS OF STRUCTURED TEACHING PPROGRAM AMONG ANTENATAL MOTHERS WITH ANEMIA AT TERTIARY CARE HOSPITAL KUPPAM, A.P
}

Mrs. Rufina S Johnson

Professor, PESCON, PESIMSR, Nalagampalle, Kuppam, Chittoor District, Andhra Pradesh, India.

\begin{abstract}
Anaemia during pregnancy in developing countries, a serious concern, besides adverse effects in the mother and foetus contributing significantly to maternal mortality. Reducing anaemia is the second global nutrition target for 2025 to bring $50 \%$ reduction in anaemia among women of reproductive age. India contributes to $20 \%$ of maternal deaths. There is a need for health education, adequate intake of iron rich diet to decrease prevalence of anaemia during pregnancy, hence the investigator is interested to educate the anaemic antenatal mothers and explore the prevalence among rural population. Randomized Control Trial was used for this study. 120, Booked cases were identified during 24-26 weeks of gestation, and 13 mothers had Normal $(\mathrm{Hb}>11 \mathrm{gm} / \mathrm{dl})$ and 107 mothers were finally identified, $\mathrm{n}-53$ in experimental and $\mathrm{n}-54$ in control group were selected to categorize mild and moderate anaemia as per WHO classification. Pre-test was assessed in both the groups and Structured Teaching Program (STP) on prevention and management of anaemia was given to experimental group for 30 minutes. Post-test knowledge scores were assessed on $8^{\text {th }}$ day after the intervention for both the groups to compare the scores. Out of 120 mothers screened during 24-26weeks of gestation 13 (11\%) mothers had Normal Haemoglobin level. Out of 107 (89\%) mothers n-53 in Experimental group 51 (96.2\%) had moderate anaemia (7-9.9gm/dl) and 2 (3-8\%) had mild Anaemia. In n-54 control group all 54 (100\%) mothers had moderate Anaemia. Hence prevalence of anaemia is $89 \%$ among rural population in Kuppam. Regarding Knowledge Scores: Pre-test: Both the groups' majority of the mothers $74-75 \%$ had poor knowledge scores. Few mothers had average scores. Post-test: In experimental group there was increase in knowledge scores from poor and average to good and very good after intervention, but in control group the knowledge remained in poor and average. Hence structured teaching program is effective. Mean was 12.08 and 1.11, SD was 2.336 and .572 and Standard means error was .321 and .078 between the two groups. Pearson chi square value was 107 with df 14 and significance of 2 sided was .000. In independent $t$ - test also the significance was .000 ( $p$ - value $<0.001$ ) hence intervention is statistically significant. Conclusion: The present study concludes that knowledge scores significantly increased in experimental group due to intervention. Recommendations: Health education and effective nursing strategies in grassroot level in community will reduce prevalence of anaemia among antenatal mothers.
\end{abstract}

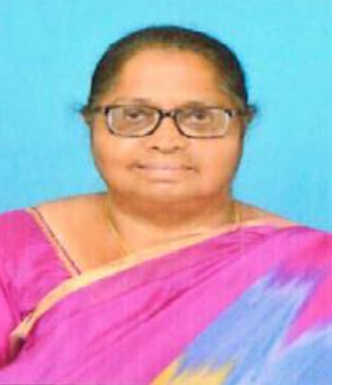

Mrs. Rufina S Johnson

Key words: Prevalence, effectiveness, Structured Teaching Program, antenatal mothers, anaemia, knowledge scores. 


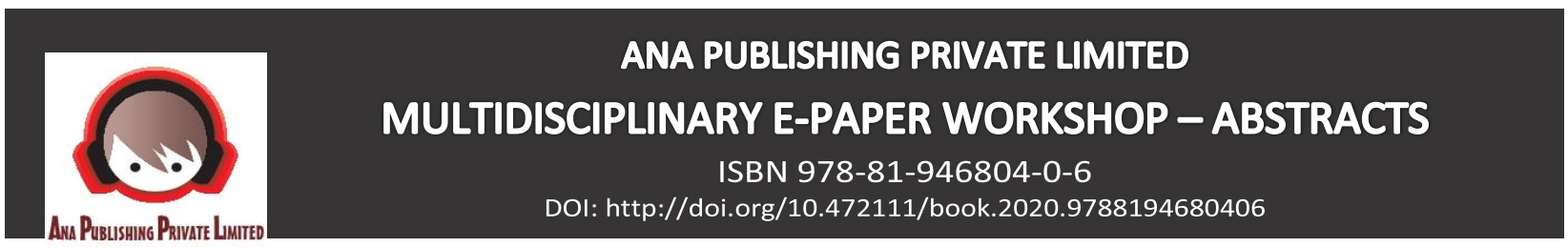

\section{ABSTRACT. 13 \\ BREAST SELF EXAMINATION FOR BREAST AWARENESS \\ Mrs. Kuldish Kaur \\ Principal, Government College of Nursing Patiala, Punjab, India.}

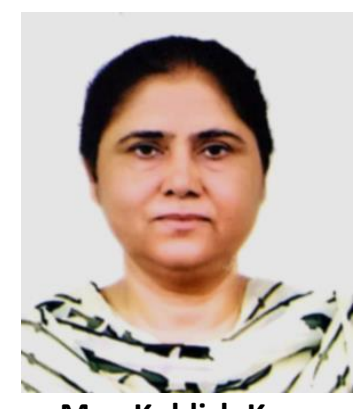

ABSTRACT:

Mrs. Kuldish Kaur

Breast self-examination for breast awareness is an inspection of the breasts that is done on one's own breast. To help increase the breast awareness, Look at the breast while standing in front of the mirror and palpate with the hands to find out if there are any changes to the look and feel of the breasts. If any new breast changes are noticed, discuss these with the doctor. Though most of the breast changes detected during breast self-examination for breast awareness have benign causes, some changes may need immediate attention as these changes signal something serious, such as breast cancer. So the steps of breast self-examination must be taught and demonstrated to every female that how to do breast self-examination to make her aware regarding her breast. Breast cancer is the most prevalent form of cancer of all female cancers. It is considered to be a progressive disease with poor prognosis if detected late. Breast self-examination is an important method of prevention of breast cancer. Routine performance of breast self-examination is recommended for females above 20 years as a preventive measure to early notice any breast changes. So breast self-examination has been shown to be effective in detecting early abnormalities and improving survival for women who have breast cancer. So it is believed that there is value in women being familiar with their own breasts, so that they can understand what's normal and what is abnormal and where to immediately report the seen and felt changes in the breasts.

Key Words: Breast cancer, breast awareness, breast self-examination. 


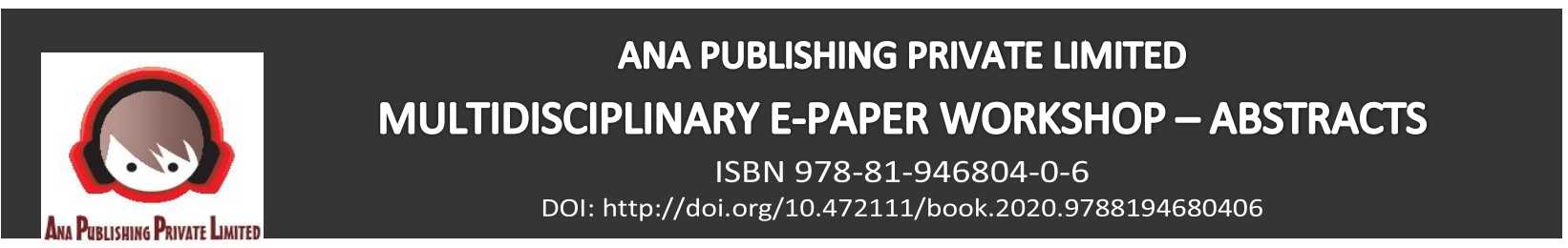

\title{
ABSTRACT. 14
}

\section{HOW TO LIVE PLASTIC FREE LIFE? \\ Mr. Aneel Kumar Dugga*| Dr. Aamarpali Roy** \\ *Ph. D Scholar, Himalyan University, Arunachal Pradesh, India. \\ **Editor-in-Chief, Ana Publishing Private Limited, India.}
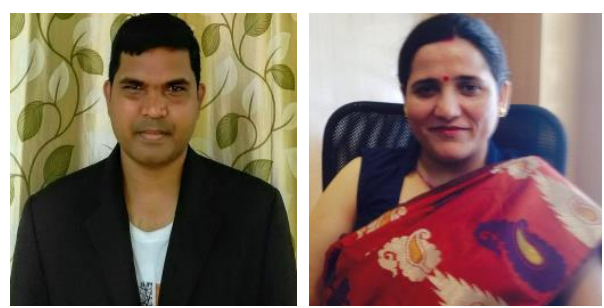

Mr. Aneel Kumar Dugga

| Dr. Aamarpali Roy

\begin{abstract}
:
Plastic pollution is the accumulation of plastic objects and particles (e.g.: plastic bottles and much more) in the Earth's environment that adversely affects wildlife, wildlife habitat, and humans. Plastics act as pollutant, it is inexpensive and durable, and as a result levels of plastic production by humans are high. Living close to nature does much good, so everybody can save the nature and live happy, now when we know plastic is one of the most important pollutants, so let's try to avoid plastic or replace plastic with nature made things, so remove plastic waste let's give this land to next generation safely. Carry reusable shopping bags, Give up bottled water, Carry your own containers for take-out food and leftovers, Stainless containers from Life Without Plastic, Stainless steel containers sold at some camping supply stores, Carry reusable utensils and glass drinking straws, Treat yourself to an ice cream cone, Cut out sodas, juices, and other plastic-bottled beverages, Let go of frozen convenience foods, Say no to plastic produce bag, Shop your local farmers market, Return containers for berries, cherry tomatoes, and other small fruits and vegetables to the farmers market to be reused, Bring your own container for meat and prepared foods, Buy fresh bread that comes in either paper bags or no bags, Choose milk in returnable glass bottles, Buy large wheels of unwrapped cheese, Choose wine bottled in glass with natural cork stoppers. So only solution to this plastic hazard is to take preventive measures and live plastic free life.
\end{abstract}

Key Words: Plastic free life, bio degradable, plastic pollution. 


\title{
ABSTRACT. 15 \\ A STUDY TOASSESS THE KNOWLEDGE REGARDING WARNING SIGNS OF PREGNANCY AMONG PRIMIGRAVID MOTHERS IN SELECTED HOSPITAL, ODISHA WITH A VIEW TO DEVELOP A SELF-INSTRUCTIONAL MODULE
}

\author{
Mrs. Anuradha Panda
}

Principal, LM college of Nursing, Bhubaneswar. Orrisa, India.

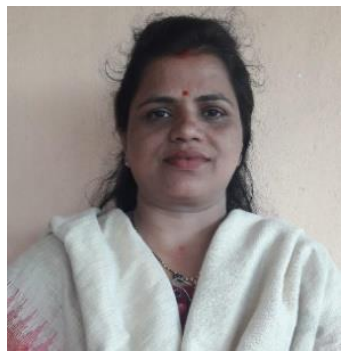

\section{ABSTRACT}

Mrs. Anuradha Panda

Few life events are as wonderful, ambivalent as pregnancy. Most of the women will have normal pregnancies with no complications, but there are certain danger signs which can result in health complication for both mother and baby. Over half a million women die each year due to complication during pregnancy and birth. Based on this view a study was conducted among 40 primigravid mothers to assess the level of knowledge regarding warning signs of pregnancy. A quantitative approach with descriptive design was adopted and data was collected by using structured knowledge questionnaire. The result revealed that majority $18(52.9 \%)$ of antenatal mothers belonged to 18-25 yrs. age group. Most i.e. 26(78.4\%) of the mothers belonged to rural area and 23(67.6\%) antenatal mothers were of gestational age 25-36 weeks. Only $2.9 \%$ had very good knowledge and $52.9 \%$ mothers had good knowledge about warning signs of pregnancy. Mean, Standard deviation and mean percentage score was observed in the area fever which was $2.4,0.99 \& 48 \%$ respectively. Chi-square test revealed there is significant association between knowledge score and selected demographic variable. Hence it was concluded that self-instructional module will be useful in improving knowledge regarding antenatal danger signs and its management.

Key Words: Primigravid mothers, antenatal danger, self-instructional. 


\section{ABSTRACT. 16}

\section{IMPACT OF COVID - 19 AMONG CHILDREN}

\section{Dr. Sathia Sweetly. S}

PHCC, Qatar

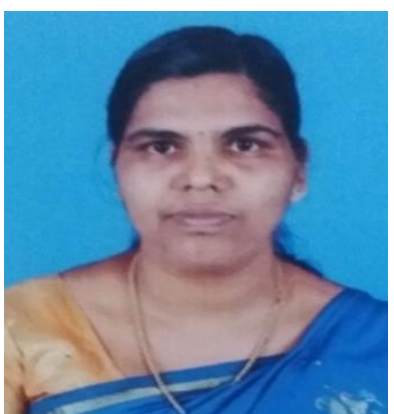

Dr. Sathia Sweetly. S

\section{ABSTRACT}

Children are not the face of this pandemic. But they risk being among its biggest victims. While they have thankfully been largely spared from the direct health effects of COVID-19 and the crisis is having a profound effect on their wellbeing. The three main channels through which they affected by this crisis - infection with the virus itself, the immediate socioeconomic impacts of measures to stop transmission of virus and end the pandemic, and the potential longer-term effects of delayed implementation of the Sustainable Development Goals. Methodology: The researcher adopted descriptive approach. The samples were the children $(n=100)$ between the age group of 5 and 15 years. Using general questionnaire the impacts were identified for the past 3 months among the children. Questionnaire was distributed and the responses recorded. Results: The findings of the study exhibit that the children were affected in different aspects like physically, psychologically, economically and socially. Most of the children facing challenges like movement limitations(homely), educational imbalances due to online classes, physically became obese, mentally disturbed due to social distancing(falling in to poverty, learning difficulties, threats to child survival and health, risk for child safety. Conclusion: To minimize the bad outcomes researcher planned to work together as a team to make progress on these three fronts-information, solidarity and action. This is an unprecedented crisis and it presents unprecedented risks to the rights and safety \& development of the world's children. Community have a chance to not only defeat this pandemic, but to transform the way nurture and invest in the young generation. But this is the time to act decisively.

Key Words: Impact of Covid on Children, Children risks Covid. 


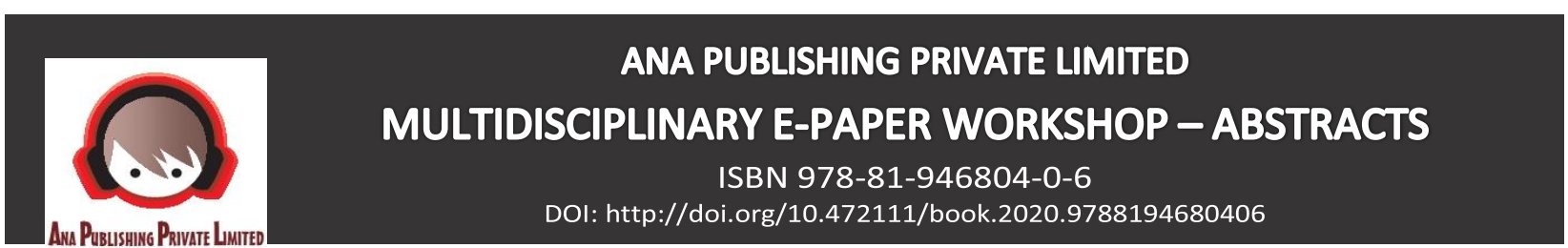

\section{ABSTRACT. 17 \\ WATER POLLUTION IN AVM CANAL: KNOWLEDGE AND ATTITUDE OF RESIDENTS}

\section{Ms. Delisha A. S}

Student, Maria Rafols Matric Higher Secondary School, Puthoor, Mondaikad, Kanyakumari, Tamilnadu, India.

\section{ABSTRACT}

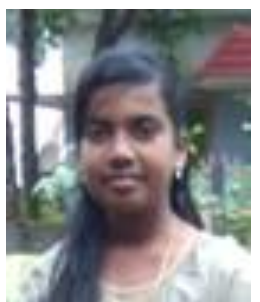

Anantha Victoria Marthandavarman Canal is generally called as AVM Canal. It was running from Kochi in Kerala to Mondaikadu in Tamil Nadu. At present, the AVM canal is completely polluted with waste. Because of pollution, the people nearby suffers with various terrible diseases like chikungunya, dengue fever and typhoid. The present study aimed at assessing the common pollutants of water in AVM Canal and attitude of residents regarding re-establishment of AVM canal for water navigation. Methods: Descriptive research design was adopted. Data was collected from 50 samples using purposive sampling. The researcher interviewed each sample with a structured questionnaire. Field visit was conducted to find out various pollutants present in AVM canal. Water sample was collected from the AVM canal for testing. Results: Almost, $74 \%$ of the participants were using the AVM canal for disposing wastes. The public drainage constructed by the Municipality drains in to the AVM canal. Around $26 \%$ of the residents reported diarrhea and $16 \%$ had typhoid in their family in the past six months. About $50 \%$ of them had good knowledge regarding water pollution and its hazards. All the participants (100\%) were willing to clean up the polluted canal and $74 \%$ were willing to reestablish the canal for boating. Conclusion: The attitude of residents towards cleaning and re-establishing the canal for water navigation is highly favourable. So it is the responsibility of the government and the NGOs to join hand with public to clean and re-establish the canal for water navigation.

Key Words: AVM canal, pollutants, re-establishment, cleaning, water pollution. 


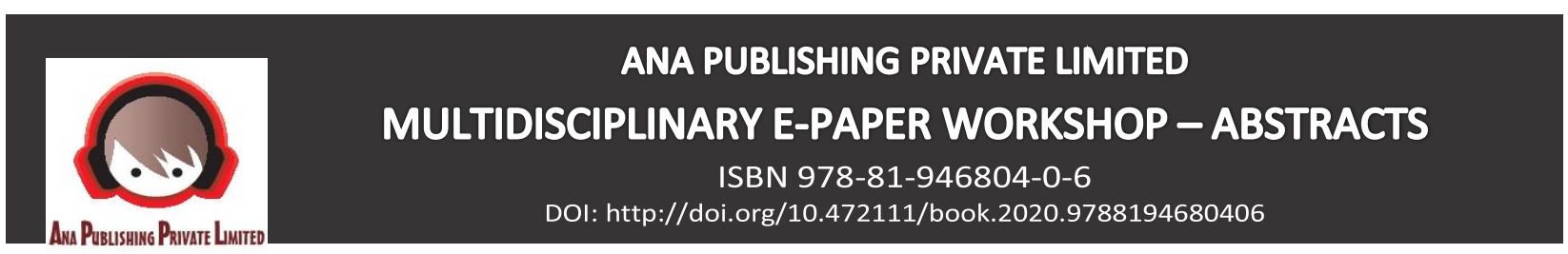

\section{ABSTRACT. 18 \\ KNOWLEDGE REGARDING DENGUE FEVER AMONG ADULTS \\ Dr. Mandeep Kaur* | Ms. Navneet Kaur** | Ms. Prabhjot Kaur** \\ *Associate Professor, CKD International Nursing College, Amritsar, Punjab, India. \\ **Nursing Student, CKD International Nursing College, Amritsar, Punjab, India.}

\section{ABSTRACT:}

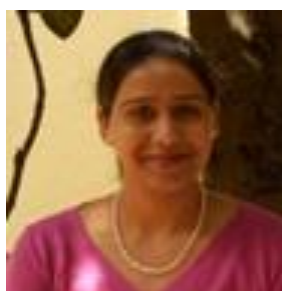

Dr. Mandeep Kaur

Dengue fever has become significant resurgent tropical disease in the past 20 year all over the globe. The health of children has important role in making nation strong because health of the children will become the health of country. Dengue fever is endemic disease, the death rate was most likely to Dengue fever and it was found that knowledge about Dengue fever in Adults was extremely poor. Dengue fever is caused by four closely related dengue viruses. There is high mortality and morbidity associated with the onset of dengue leading to great socio economic impact. As longevity increases, more and more cases need treatment. The main aim of the study is to assess the knowledge regarding dengue fever among adults in selected area of Amritsar, Punjab. A descriptive study on 150 adults of age group of 21-40 in Amritsar was documented to assess the knowledge regarding dengue fever. For this study, Purposive sampling technique was used for collecting data regarding knowledge of dengue fever. The study revealed that only $68(45.3 \%)$ adults had adequate knowledge and $82(54.6 \%)$ adults had inadequate knowledge regarding Dengue fever. Booklet was distributed among adults which include knowledge regarding dengue fever. Hence, it is concluded that there is need to foster awareness regarding dengue fever among adults. Improved health care programmes about dengue fever might help give adults a better quality of life.

Key Words: Dengue Fever, adults, Knowledge. 


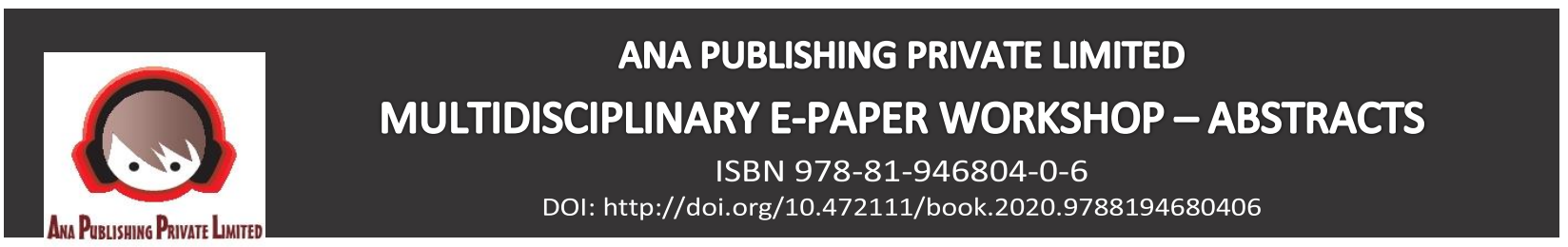

\title{
ABSTRACT. 19 \\ A STUDY TO ASSESS THE EFFECT OF STRUCTURED TEACHING PROGRAMME RELATED TO IMPORTANCE OF ORGAN DONATION AMONG ADULTS OF LUCKNOW CITY
}

Mrs. Sheela Rajeev Tiwari

Principal, Bora Institute of Allied health Sciences, Lucknow, Uttar Pradesh, India.

\begin{abstract}
Mrs. Sheela Rajeev Tiwari

Organ donation is the process when a person allows an organ of their own to be removed and transplanted to another person, legally, either by consent while the donor is alive or dead with the consent of the next of kin. Transplantation is necessary because the recipient's organ has failed or has been damaged by disease or injury. On an average 20 people, die every day from lack of available organs for transplant. One deceased donor can save up to eight lives through organ donation and can save and enhance more than 100 lives through the lifesaving and healing gift of tissue donation. Aim of the study: There is a large gap between the numbers of registered donors compared to those awaiting organ donations on a global level the researcher felt the need to educate the people on importance of organ donation. An evaluative one group pre-test posttest was conducted to assess the effect of structured teaching programme on importance of organ donation among 100 samples of selected areas of Lucknow city. The teaching programme covered areas like Awareness, facts and Misconceptions about organ donation. The procedure of organ donation and organisations working for organ donation were also discussed. The data analysis was done using descriptive and inferential statistics. The mean of pre-test level of knowledge was 6.71with a standard deviation of 3.642 .The mean of post-test level of knowledge was 19.05 with a standard deviation of .757.Calculated t value was- 29.967 and $P$ value is .001 which was greater than the table value at 0.05 level of significance. There is a significant increase in knowledge after the administration of teaching shows that teaching was effective in improving the knowledge on importance of organ donation.
\end{abstract}

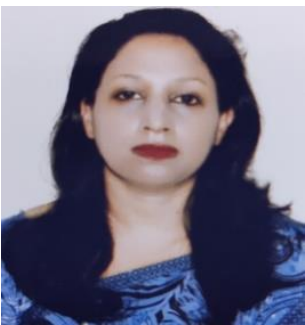

Key Words: Structured teaching programme, Organ donation. 


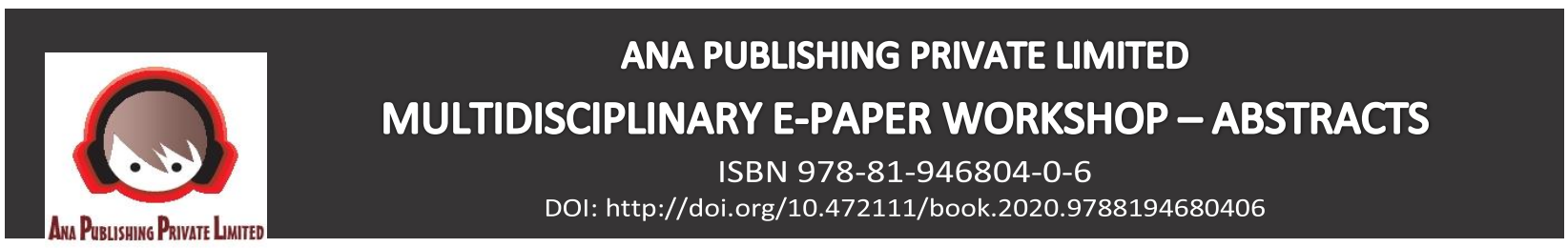

\section{ABSTRACT. 20 \\ CHALLENGES IN LEARNING AND TEACHING SECOND LANGUAGE \\ Ms. Romy Khuranna ${ }^{*}$ I Dr. Shaifali Rachna Puri ${ }^{* *}$ \\ *Assistant Professor, ACET, Amritsar, Punjab, India. \\ ${ }^{* *}$ Director, Ana Publishing Private Limited, India.}

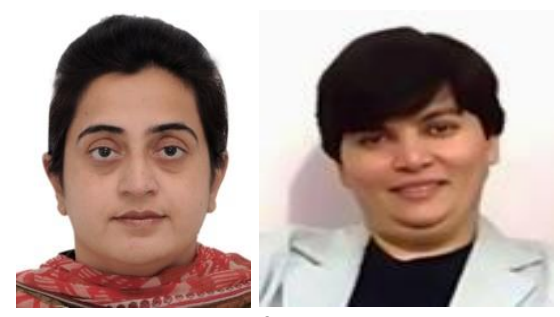

\section{ABSTRACT}

Ms. Romy Khuranna | Dr. Shaifali Rachna Puri

It is globally accepted that English language has become the lingua franca in this age of globalization. Today perhaps 1.5 billion people are using this language across the world. Learning and using English is much required unifying chord in today's time. Due to its extensive use in all the essential fields of man's life like medicine, education, science, technology, engineering, international communication etc., its teaching is resulting in huge demand throughout the globe. With every growing second, it is getting the status of world language. Thus learning and teaching English has long been of interest for educators. Everyone has constantly tried to reduce the obstacles in the path of learning this language but very few have been able to do so. Many learners and teachers encounter the problems that hamper the complete learning of this language. Although the students spend a lot of time in their classes to learn this language but still that are unable to achieve the desired result. We need to work upon the deficiencies that exist in teaching and learning this language. Learning and teaching English as a second language is quiet challenging and need to be focused upon. Thus students and educators need to be extra careful in the acquisition of second language. English gives us an access to the world. Today English certainly deserves to be regarded as a "world" language. We need to sow the seeds of this language at an initial stage of teaching. It needs to be understood that it is no more a foreign language but it is the language required by the world for greater understanding. It is not now "Their" language but it is "ours".

Key Words: English Language, World language, second language. 


\title{
ABSTRACT 21 \\ ASSESSMENT OF KNOWLEDGE AND ATTITUDE OF PARENTS REGARDING UNIVERSAL IMMUNIZATION PROGRAMME (UIP)
}

\author{
Dr. Ashok Kumar Dhanwal \\ Nursing Officer, PGIMER \& RMLH, New Delhi, India.
}

\begin{abstract}
Immunization is vital; it protects nearly $3 / 4^{\text {th }}$ of children against major childhood illness. There are several diseases which can be easily prevented by timely vaccination as part of routine immunization. India's vaccine deficit has several causes like poorly educated population or lack of awareness among people. Aim; To assess the knowledge and attitude of parents regarding universal immunization programme. To determine the significant association of knowledge and attitude with selected demographic variables and To teach a health education module on UIP of India. Material and methods; an exploratory descriptive survey method was used as a research design. Statistics was accumulated with the aid of convenient sampling method from 500 parents of selected rural areas of Jaipur city. The tool included ten demographic variable and 30 established questions regarding knowledge and attitude on immunization. Descriptive and inferential statistics were used for analysis. Conclusion: The study revealed that the majority of parents have moderate score of knowledge $59.8 \%$ regarding immunization where as $40.2 \%$ have inadequate level of knowledge. It is also depicts that none of them have adequate level of knowledge regarding immunization. And the attitude score calculated that $20.6 \%$ parents have positive attitude towards immunization of under-five children whereas majority of parents $77.4 \%$ have no opinion or don't know regarding child immunization and only $2 \%$ parents have negative attitude towards child immunization. there is significant association between the score level of knowledge and selected demographic variables like (age, religion, monthly income, education, type of family, source of acquiring knowledge and status of immunization).There is no significance association between the level of knowledge scores and other demographic variables like (sex, occupation and number of under-five year children) The calculated chi-square values were less than the table value at the 0.05 level of significance. There is significance association between the score level of attitude and demographic variables (age, numbers of under-five children in family, religion, occupation, monthly income and education). There is no significance association between the level of scores and other demographic variables (sex, type of family, source of acquiring knowledge and status of immunization) The calculated chi-square values were less than the table value at the 0.05 level of significance.
\end{abstract}

Dr. Ashok Kumar Dhanwal

Key Words: Knowledge, attitude, universal immunization programme, parents. 


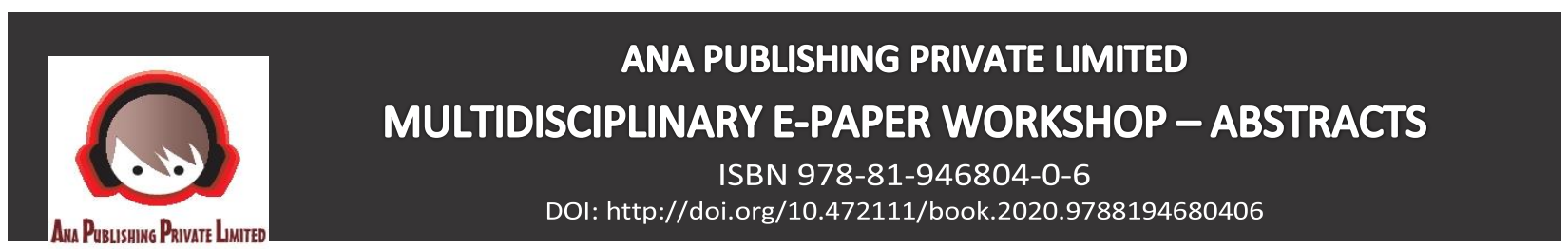

\title{
ABSTRACT. 22 \\ A STUDY TO ASSESS THE SELF-ESTEEM \& ATTITUDE TOWARDS NURSING PROFESSION AMONG FINAL YEAR NURSING STUDENTS STUDYING IN D. Y. PATIL COLLEGE OF NURSING, KOLHAPUR
}

\author{
Mr. Praveen L Subravgoudar
}

Associate Professor, D. Y. Patil College of Nursing, Kadamwadi, Kolhapur, India.

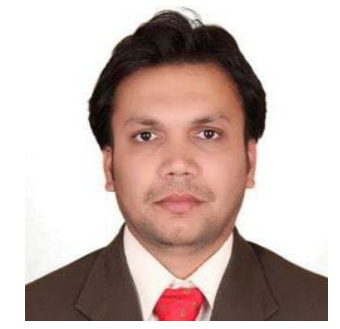

\section{ABSTRACT}

Mr. Praveen L Subravgoudar

Self-esteem is one of our basic Psychological needs. The degree of our basic psychological needs: The degree of our self-esteem impacts every major aspect of our lives. It has profound effect on our thinking processes, emotion, desire, values, choices and goals. Deficits in self-esteem contribute to virtually all psychological problems. And psychological problems lead to lowered self-esteem. It is a reciprocal relationship. The concept we form of ourselves, stated positively, I our self-esteem. Understanding attitudes, competencies, and the intended work location among nursing students may help inform policy as well as helping in the design of interventions that would encourage nurses to choose to work in rural areas where they are most needed. The present study is aimed at assess the Self-Esteem \& Attitude towards Nursing Profession among final year nursing students studying in D. Y. Patil college of nursing, Kolhapur". The objectives are as follows, 1 . To identify the level of self-esteem among the students. 2. To identify the level of attitude among the students. 3. To find a correlation between level of self - esteem score and attitude score among the students. 4 . To find a significant association between level of self-esteem score with their selected demographic variable among students. 5. To find a significant association between attitude score with their selected demographic variable among students. Methods: A Non-experimental descriptive correlational research design was used for this study. Hundred final year nursing students studying in D. Y. Patil College of nursing were selected by Nonprobability convenient sampling technique and the data was collected by using Modified self-esteem scale \& Attitude Scale. Result: The study finding of the self-esteem score of final year nursing student revealed that $44 \%$ had High level of self-esteem, $54 \%$ had Optimum level of self-esteem, whereas majority $2 \%$ had Medium level of self-esteem as well as $96 \%$ had positive attitude \& $4 \%$ had negative attitude towards nursing profession. The Result of Correlation indicates $(r=0.63)$ moderately positive correlation between Self Esteem \& Attitude Score towards nursing profession among final year nursing students. The finding also shows that there was association between the Self-esteem scores with Gender of final year nursing students. Interpretation and conclusion: The finding reveal that most of the Final year nursing students had (96\%) positive attitude \& $54 \%$ had optimum level of self-esteem towards nursing profession. The result of correlation between Self Esteem \& Attitude Score towards nursing profession among final year nursing students indicates $(r=0.63)$ moderately positive correlation. The finding shows that there was association between the self-esteem scores with gender of final year nursing students studying in D. Y. Patil College of Nursing, Kolhapur.

Key Words: Self-esteem, psychological needs, nursing profession. 


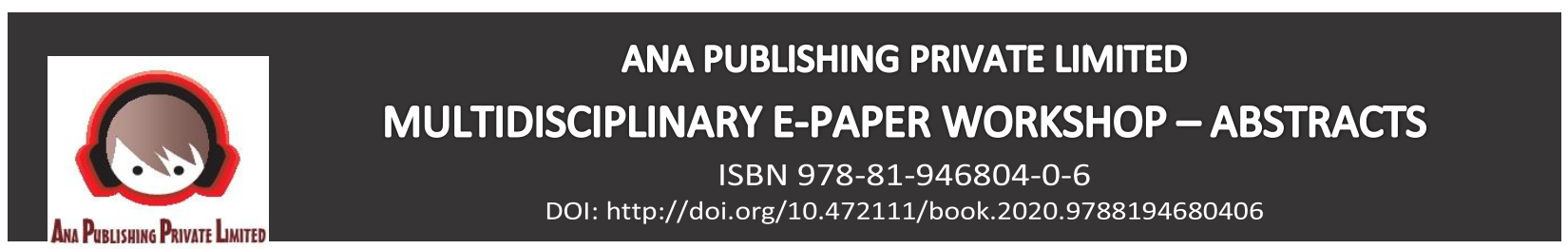

\title{
ABSTRACT. 23 \\ EFFECTIVENESS OF STRUCTURED TEACHING PROGRAMME ON SEX AWARENESS AMONG ADOLESCENT GIRLS
}

\author{
Dr. M. B. Aruna Arputhamalar
}

Principal, Aragonda Apollo College of Nursing, Andhra Pradesh, India.

\begin{abstract}
Adolescence is a period of rapid development, with marked physical social, emotional and cognitive changes, indicated by emergence of secondary sexual characteristics and attainment of reproductive maturity, where health problems, is a challenge. Development includes integrated and internalized sense of identity, and menarche as prominent change. Awareness on sex education is vital, which includes structure and functions of female reproductive organs, menstrual hygiene, problems of adolescents, Sexually Transmitted Infections. Need for the study: Adolescent girl's experiences various changes may lead to mal adjustment deviation in concentration could be due to lack of sex awareness. Sex education involves acknowledgement and understanding of the process of sexual development and interaction that affects the individual for rest of her life. Methodology Design: True Experimental Design. Settings: Zilla Parishad Girls High School, Aragonda. Population: Adolescent Girls with Age group12-15 yrs., studying in $7^{\text {th }}-10^{\text {th }}$ class. Sample: 30 as 15 in control and 15 in experimental group. Sampling technique: Simple Random Sampling, lottery method. Sampling criteria: adolescent girls attained menarche, with the age $12-15 y$ rs, studying in $7^{\text {th }}-10^{\text {th }}$ class at Z. P. High School, Aragonda. Data collection procedure: a pre test, using a self-administered questionnaire was conducted. A structured teaching Programme was conducted after a week time; post test was conducted using the same questionnaire. Tool: self-administered questionnaire, consisting of sec I-demographic variables, secII-Questions on the various aspects of sex education like, structure and functions of reproductive system, menstrual hygiene, problems of adolescent girls, sexually transmitted infections. Scoring: Totally 33 Questions were there and each correct answer carried One Mark. Score interpretation: $\geq 80 \%$ : Excellent $60-79 \%$ : good, 40-59\%-average, $\leq 39$ \%: poor. Pilot study: done using 8 samples. (4+4). Data Analysis: Descriptive Statistics was used. Major findings of the study: The level of knowledge regarding all aspect of sex awareness was low as evidenced by the mean pre-test value, as shown in table. The mean pre-test and post-test values of level of knowledge among experimental and control group reveal that the structured teaching programme on sex education was highly effective in creating awareness among adolescent girls. The analysis of association of selected demographic variable such as age and education with level of knowledge among adolescent girls revealed that $13 y$ rs of age group had more knowledge than the higher age group of $14 \mathrm{yrs}$. and $15 \mathrm{yrs}$. and $9^{\text {th }}$ standards students had more knowledge than the $10^{\text {th }}$ standard students.
\end{abstract}

Dr. M. B. Aruna Arputhamalar

Key Words: Structured teaching programme, sex awareness, adolescent girls. 


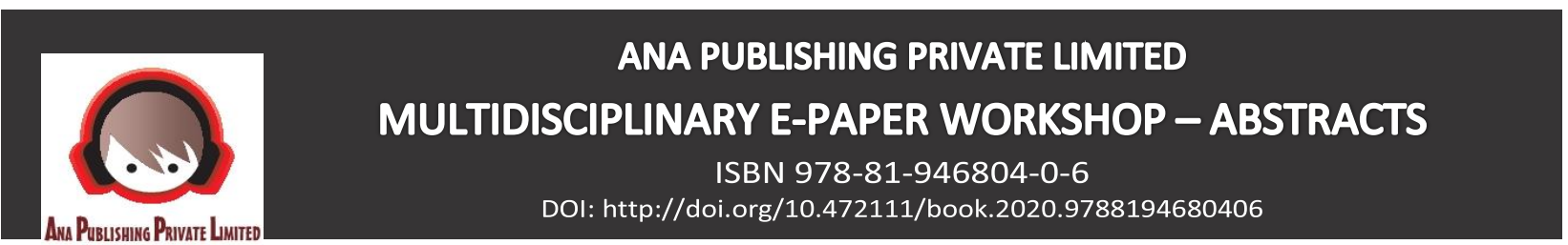

\title{
ABSTRACT. 24 \\ THE IMPACT OF SOCIO-ECONOMIC STATUS ON LEARNING ENGLISH AMONG CHILDEN OF KAMRUP, INDIA
}

\author{
Ms. Chitra Sharma * | Dr. Shaifali Rachna Puri ${ }^{* *}$ \\ *Ph. D Scholar, Himalayan University, Arunachal Pradesh, India. \\ **Director, Ana Publishing Private Limited, India.
}
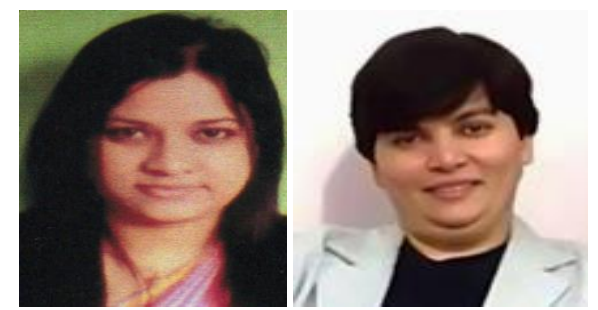

Ms. Chitra Sharma | Dr. Shaifali Rachna Puri

\section{ABSTRACT:}

English is contemplated as the most prestigious language on account of its extreme presence in the contemporaneous world. Appreciating the significance of this cosmopolitan language, the administration of India has launched myriad schemes and strategies to learn English even as obligatory. But woefully, the scenario of Kamrup, the capital district of Assam, India is convoluted. Socio-economically needy parents who are normally low-wage workers, indigent peasants, impecunious venders or peddlers, use to enrol their children to vernacular schools but during flood, the impoverished students have to fight for survival instead of attending schools. Even many government schools remain closed and converted into flood relief camps in flood affected areas. Flood is the burning problem of Assam and the socio-economically necessitous students are the ultimate victims of this disastrous natural calamity. In harvesting time also, the children of povertystricken peasants assist their parents in cultivated fields. As a result, they are mislaying the opportunity to learn English throughout the year. Such parents are not educated enough to embolden their kids in studies, especially in English. They are amateurish to provide sufficient study materials and helpless to fabricate uninterrupted learning atmosphere at home which executes an essential lump in the learning process. This presentation will be beneficial to scrutinize the odds and hurdles of socio-economically backward children while learning English and can expand the path of finding solutions of such challenges.

Key Words: Impact of socio-economic status, learning English, children of Kamrup. 


\section{ABSTRACT. 25 \\ EVALUATING THE KNOWLEDGE, PERCEPTION AND ATTITUDE OF STUDENTS OF GOVERNMENT SCHOOLS TOWARDS HIV/AIDS IN SHIMLA}

\section{Dr. Seema Chauhan*I Dr. Shama Lohumi**}

*Lecturer, Sister Nivedita Govt. Nursing College (IGMC), Shimla, Himachal Pradesh, India. ** Principal, Shivalik Institute of Nursing, Sanjauli, Shimla, Himachal Pradesh, India.

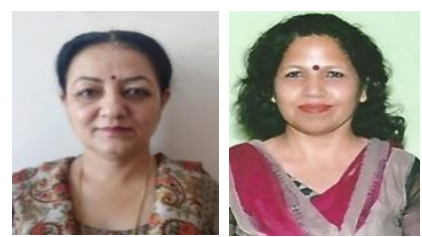

Dr. Seema Chauhan I Dr. Shama Lohumi

\section{ABSTRACT}

Introduction: HIV/AIDS is one of the most complex health problems of the 21st century. The Objective of our study is to assess the knowledge, perception, attitude level among the students of Government schools regarding HIV/AIDS in Shimla. Material \& methods: The present study comprised of 400 students studying in 4 higher secondary schools selected randomly in the age group of 14-19 years. The data obtained through structured questionnaire was analysed using both descriptive and inferential statistics with the help of Epi info v7 software. Results: In the present study most of the students (55.5\%) were in the age group of 17-19 years, maximum (60\%) were male and $56.5 \%$ were in $10+2$ class. $2.75 \%$ students having very good knowledge about HIV/AIDS and $23.25 \%$ students having poor knowledge. $1.3 \%$ students having very good attitude and $14.8 \%$ having poor attitude. $1.8 \%$ students having very good perception and $16.5 \%$ having poor perception .Mean marks of knowledge, attitude and perception of students were $10.03 \pm 3.019,34.94 \pm 5.432$ and $35.01 \pm 5.055$ respectively.Good knowledge was significantly associated with $17-19$ years age group,10+2 class, joint family, higher educational level of father, higher educational level of mother and family having Monthly Income $>$ Rs 10,000. Conclusion: Our study indicates the presence of substantial lacunae in knowledge regarding AIDS in the population studied. There is need to further increase the knowledge and to clear the misconceptions regarding the disease.

Key Words: HIV/AIDS, Knowledge, Perception, Attitude level. 


\title{
ABSTRACT. 26 \\ KNOWLEDGE REGARDING DIARRHEA AND ORS PREPARATION AMONG POSTNATAL MOTHERS
}

\author{
Dr. Arundeep Kaur*|Mrs Jasdeep Kaur**| Ms. Harmanpreet Kaur** |Ms. Jyoti Sharma** \\ *Associate Professor, CKD International Nursing College, Amritsar, Punjab, India. \\ **Nursing Student, CKD International Nursing College, Amritsar, Punjab, India.
}

\section{ABSTRACT:}

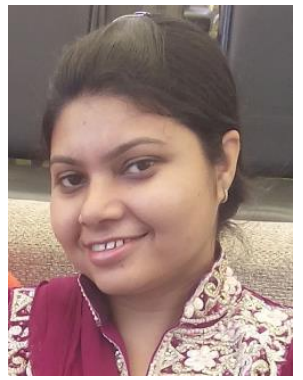

Dr. Arundeep Kaur

Diarrhoea is a major cause of illness and death among young children in developing countries. Globally, as an estimated 1.8 billion episodes of childhood diarrhoea occur every year a higher annual incidence than that of any other disease and more than three million children die from diarrhoea or diarrhoea related causes annually. As in developing countries diarrhoea is major cause of illness and death among children in India. A study showed that many families required travelling to a health care provider, which may take a significant amount of time and require an unanticipated cost. While PHCs provide free treatment and distribute free ORS packets. The cost of getting to the clinic may still be viewed as greater than the benefit. About $30 \%$ of people living in rural area reported that they did not visit a health care provider if their children experienced diarrhoea. So researcher found that there is need to provide the knowledge regarding Diarrhoea and ORS to postnatal mothers. Therefore this study was conducted with pre-experimental research design. The setting of the study was verka community centre, Amritsar. Study was conducted among 60 postnatal women who were selected by purposive sampling Technique. A self-structured questionnaire was proposed to assess the knowledge and practices. Results revealed that most of the postnatal women were homemaker (70\%) and received information about diarrhoea from health workers (83.33\%) . it is concluded that structured teaching programme has significant effect in increasing the knowledge of post natal women regarding diarrhoea and ORS preparation.

Key Words: Diarrhoea, childhood diarrhoea, postnatal mother. 


\section{ABSTRACT. 27 \\ A STUDY TO ASSESS THE EFFECTIVENESS OF BIBLIOTHERAPY ON STRESS AMONG CANCER PATIENTS IN SELECTED CANCER HOSPITALS, AT ERODE DISTRICT}

Mr. Kodeeswaran A.

Assistant Professor, Dr. Mahalingam college of Nursing, Erode, Tamilandu, India.

\section{ABSTRACT:}

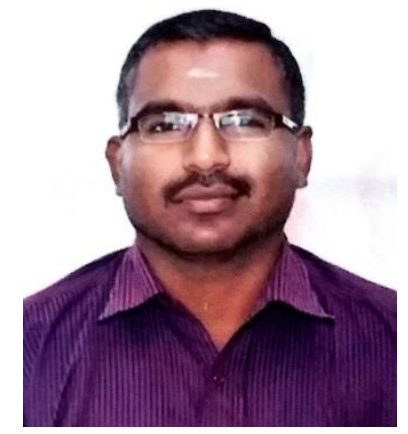

Stress describes what people feel when they are under mental, physical, or emotional pressure. Although it is normal to experience some psychological stress from time to time, people who experience high levels of psychological stress or who experience it repeatedly over a long period of time may develop health problems (mental and/or physical). A disease such as cancer is often one of the most stressful experiences of a person's life. The research approach used for this study was evaluative approach and research design was True Experimental Design. The total number of samples taken was 60 , among those 30 samples was in experimental group and whereas 30 samples in control group that was selected for the study by using simple randomized technique. Descriptive statistics (frequency, percentage, mean, and standard deviation) and inferential statistics (chi- square, paired ' $\mathrm{t}$ ' test and unpaired ' $\mathrm{t}$ ' test were used to analyze the data and to test hypothesis.

The result of the study showed that the pre-test level of stress. The mean score in experimental group is Mild $2(7 \%)$, Moderate $6(20 \%)$ and Severe 22 (73\%) whereas, it was reduced in the post-test with means score mild $18(60 \%)$, moderate $10(33.3 \%)$ and severe $2(6.6 \%))$. It states that Bibliotherapy has an impact on stress among cancer patients in experimental group. The computed ' $\mathrm{t}$ ' value 11.353 was higher than the calculated value at 0.05 level of significance. Hence, $\mathrm{H}_{1}$ (there is significant difference between pre-test and post-test level of stress among cancer patients in experimental group) was accepted.

The post-test overall stress score in experimental group. The mild 18(60\%), moderate 10(33.3\%) and severe 2 $(6.6 \%)$ and where as in control group mild $2(6.6 \%)$, moderate $9(20 \%)$ and severe $22(73.3 . \%)$.

The comparison between post-test level of stress score in experimental group and control group. showing the value are significant which was observed from unpaired' $t$ ' test value of 9.833 at 0.05 level of significance, which is evident for the effect of Bibliotherapy in reducing stress level among cancer patients. Hence, $\mathrm{H}_{2}$ (There is significant difference in post-test level of stress among cancer patients in experimental group and control group) was accepted.

There is significant association between pre-test level of stress and demographic variables such as sex, habit and other relaxation techniques. The findings of the study support the need of awareness regarding bibliotherapy among nurses. The study was proved that the cancer patients had remarkable decrease in stress level after Bibliotherapy. The findings of the study proved that the Bibliotherapy on stress among cancer patients was effective in reducing the level of stress. The study revealed that irrespective of variations in demographic variables, all patients in experimental group showed reduction in level of stress with Bibliotherapy.

Key Words: Effectiveness, Bibliotherapy, cancer, stress 
ABSTRACT. 28

\section{A STUDY TO EVALUATE THE EFFECTIVENESS OF STRUCTURED TEACHING PROGRAMME (STP) ON KNOWLEDGE REGARDING WIFS PROGRAMME AMONG ADOLESCENTS}

Ms. Komala. H. K

Professor, Department of Community Health Nursing Adichunchanagiri College of Nursing, Adichunchanagiri University., Mandya (Dist), Karnataka, India.

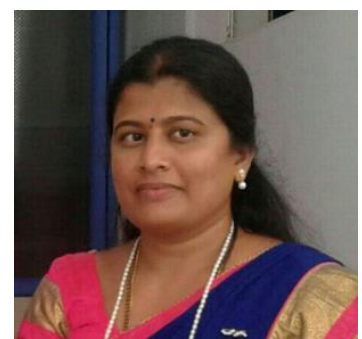

Ms. Komala. H. K

\section{ABSTRACT}

Adolescence is a vulnerable period in the human life cycle for the development of nutritional anaemia, which has been constantly neglected by public health programs and is at high risk of iron deficiency anaemia due to accelerated increase in requirements for iron, as well as the social norm of early marriage and adolescent pregnancy. During this stage the requirement of nutrition and micronutrients is relatively high Objectives: 1 . to assess the pre-test level of knowledge regarding WIFS programme among adolescents. 2. To assess the posttest level of knowledge regarding WIFS programme among adolescents. 3. To evaluate the effectiveness of structured teaching programme on knowledge regarding WIFS programme among adolescents. 4 . To find out the association between gain in knowledge scores with selected demographic variables. Methodology: The Quasi-experimental study design was adopted for the study. The 60 samples were selected based on the randomisation. Pre tested, validated self-administered tool was used to collect the data. Result: The results shows that in the pre-test majority of the adolescent school children (68.3\%) having poor knowledge on WIFS programme, but in post-test majority of the adolescent school children (73.3\%) having average knowledge on WIFS programme The paired ' $\mathrm{t}$ ' test computed between pre and post-test knowledge score was statistically significant at 0.05 level of significance. The calculated ' $\mathrm{t}$ ' value 11.17 is greater than table value $\left(\mathrm{t}_{(59)}\right)=1.96$. The result shows there is a significant association between the gain in knowledge scores of adolescent WIFS programme among adolescents with selected demographic variables like age $\left(x^{2}{ }_{(2)}=8.28\right)$, sex $\left(x^{2}{ }_{(1)}=8.13\right)$, education of father $\left(\mathrm{x}^{2}(1)=4.34\right)$. Interpretation and conclusion:

The results showed that the mean post test score higher than mean pre-test score. Thus it can be concluded that there is significant improvement in the knowledge of adolescents regarding WIFS programme after the administration of structured teaching programme.

Key Words: WIFS programme, adolescents, structured teaching programme. 


\title{
ABSTRACT. 29 \\ IMPACT OF SMARTPHONE ADDICTION ON SOCIAL AND EDUCATIONAL LIFE OF ADOLESCENTS
}

\author{
Mrs. Jasintha. S
}

Principal, Paradkar Nursing Institute, Paradkar Hospital and Research centre campus, Narsinghpur, Madhya Pradesh, India.

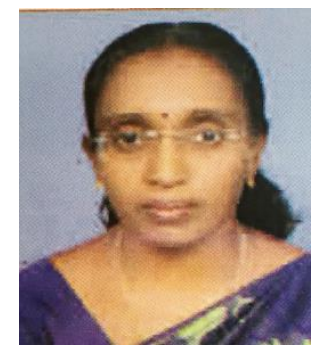

\section{ABSTRACT}

Mrs. Jasintha. S

Smartphone is a mobile phone that includes advanced functionality beyond making phone calls and sending text messages. Smartphone addiction is an excessive use of smart phones. This study investigated the level of Smart phone addiction among Adolescents and Impact of Smart phone addiction on Social and Educational life of Adolescents. In explorative research design, 50 Adolescents were selected through the Convenience sampling technique filled out a Questionnaire that included Socio- Demographic variables, Check list on levels Smartphone addiction and Rating Scale on impact of Smartphone addiction on Social and Educational life of adolescents. $22 \%$ of Adolescents had severe Smartphone addiction. Chi-square test was used to assess the impact of Smartphone addiction on social and educational life of Adolescents. On social life, chi-square value was $41.39(P=0.000002)$. Hence there was a significant impact on Social life. On educational life, chi-square value was 40.02 ( $P=0.000007)$. Hence there was a significant impact on Educational life. The association found between the level of Smartphone addiction and selected demographic variables such as Age and Number of Smartphone available in home and there was no association found with demographic variables such as Gender. The prevalence of Smartphone use among Adolescents was quite high. Only $10 \%$ of adolescents had No addiction. Study concludes that Smart phone addiction gives negative impact on social and educational life of adolescents.

Key Words: Smartphone, Smartphone Addiction, Social life, Educational life, Adolescents. 


\section{ABSTRACT. 30 \\ TO ASSESS KNOWLEDGE AND ATTITUDE REGARDING GENETIC COUNSELLING AMONG MARRIED WOMEN IN SELECTED AREAS}

Mrs Paramjit Kaur

Principal Government Institute of nursing and paramedics (INC \&amp; PNRC Affiliated) Civil Hospital Ropar, Punjab. India.

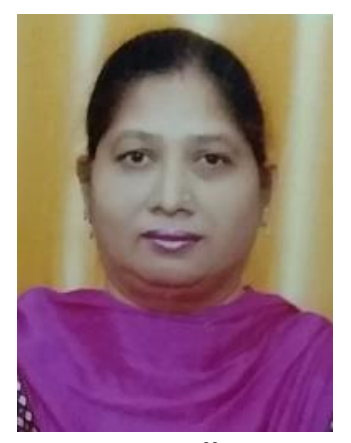

\section{ABSTRACT}

Mrs Paramjit Kaur

Genetics is the study of genes, what they are and how they work. Genes are units inside a cell that control how living organisms inherit features from their ancestors. Genetic disorders are transmitted from parent to the offspring through a specific pattern of inheritance exemplified by recessive genetic disorder. Genetic counselling is a vital part of the field of medical genetics. Genetic counselling is the process by which patients or relatives, at risk of an inherited disorder, are advised of the consequences and nature of the disorder, the probability of developing or transmitting it, and the options open to them in management. Genetic counselling provides information about the condition running in the family and its impact. As the genetic counselling is so much helpful to reduce the infant mortality rate and save the life of women and their offspring. The researcher wanted to assess the knowledge and attitude of married women regarding genetic counselling. Design: A nonexperimental correlational research design was used with non-probability convenient sampling technique. Material \& Methods: The study consisted of 60 married women .Data was collected by using self-structured questionnaire to assess knowledge and likert rating scale to assess attitude. Analysis was done by both descriptive and inferential statistics. Findings: The study findings showed that $75 \%$ women had poor knowledge, $21.7 \%$ had average knowledge and 3.3\%had good knowledge regarding genetic counselling. $96.7 \%$ had positive attitude and $3.3 \%$ had neutral attitude regarding genetic counselling.

Conclusion: The study concluded that married women had poor knowledge and positive attitude regarding genetic counselling. There was weak positive correlation between knowledge and attitude regarding genetic counselling Hence research hypothesis accepted and null hypothesis is rejected.

Key Words: Genetics, Genes, Genetic disorders, Genetic counselling. 


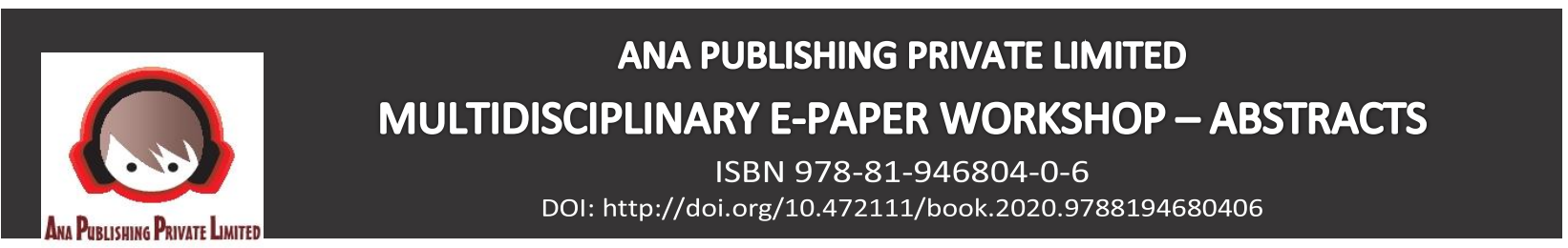

\title{
ABSTRACT. 31 \\ ASSESSMENT OF RISK FACTORS AND QUALITY OF LIFE AMONG NURSES WITH VARICOSE VEINS AT TERTIARY HEALTH CARE HOSPITALS, CHENNAI
}

\author{
Mrs. Savithri K. B* | Dr. Raj Rani**
}

*Associate Professor, Panimalar College Of Nursing, Chennai, Tamil Nadu, India. **Principal, GTB, Jandiala Guru, Amritsar, Punjab, India.

\section{ABSTRACT}

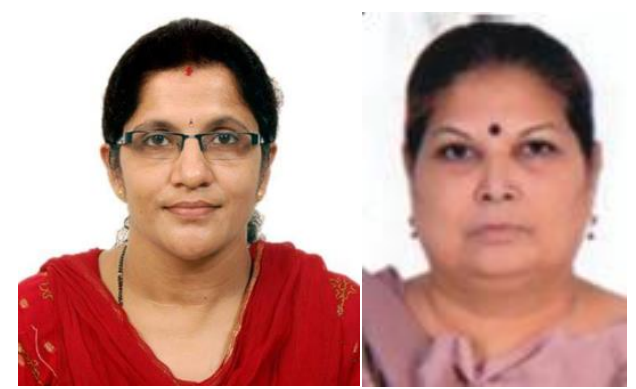

Mrs. Savithri K. B | Dr. Raj Rani

Work-related health problems are common among nurses. There are various work-related health problems among them low back pain, hypertension and Varicose vein are most evident. High prevalence of varicose veins and its complications is an emerging problem in the twenty-first century. This study aimed to determine the associated risk factors and Quality of life (QoL) among nurses with varicose veins. Methods: In this crosssectional study, 96 nurses working in tertiary health care centre in Chennai were participated. Standard physical examination was used to check the condition of varicose veins in the lower extremities of participants. Data collected by using structured interview with the tool, Ware et al. (1993) RAND- 36 Item Short Form Health Survey (SF-36) for Quality of life (QoL) and background variables. Results: Varicose veins were significantly associated with age family history of varicose disease, blood pressure and long standing. The results of the study depicted that $78 \%$ patients had poor QoL. The mean percentage of composite summaries of QoL was low QoL in all its spheres. A statistically significant association was noted between the mean score of QoL and type of exercise at $p<.0001$. Conclusions: A varicose vein was associated with risk factors such as increasing age, family history of varicose disease, high blood Pressure, and prolonged standing. The present study makes evident that majority of the nurses with varicose vein has poor QoL and it affects all dimensions of QoL.

Key Words: Health problems among nurses, low back pain, hypertension and varicose vein. 


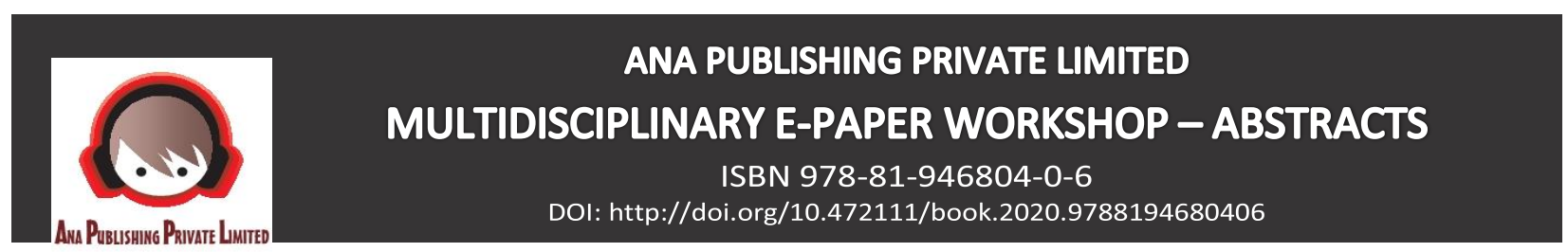

\title{
ABSTRACT. 32 \\ MENTAL HEALTH PROMOTION AND EARLY IDENTIFICATION OF MENTAL ILLNESS AMONG ADOLESCENTS
}

\author{
Mr. Jibin Varghese*| Dr. Amandeep Kaur** \\ Principal, Aarihant Institute of Nursing, Gandhinagar, Gujarat, India. \\ **Executive Editor, Ana Publishing Private Limited, India.
}

\begin{abstract}
A proper mental health during childhood is prerequisite for optimal psychological development, social relationships, learning and the ability to care for one's self. The aim of the present study is to assess the knowledge regarding mental health promotion and early identification of mental illness in adolescence among teachers and to find out the relationship between pre \& post-test knowledge of samples with selected demographic variable. Adolescence is a unique and formative time. The necessity of emotional health in teenagers, are pre-essential for their psychological, social, physical, intellectual and instructive improvement, which are much perceived. The mental health need of children and adolescence within worldwide have received increasing attention in recent years. A proper mental health during childhood is prerequisite for optimal psychological development, social relationships, learning and the ability to care for one's self. Mental health is a positive concept related to the individual's social, emotional, and psychological well-being. Mental health services embedded within school systems can create a continuum of integrative care that improves both mental health and educational attainment for children. Childhood psychiatric disorders are associated with educational failure, which in turn is associated with increased rates of psychiatric disorders and both are associated with a range of additional adverse outcomes, including risk-taking behaviour and being more likely to enter the criminal justice system. Teachers have a major influence on the development of children, including their social and emotional development. Although teachers reported mental health knowledge and skills to be important when working with children, they also acknowledged their lack of training in that area. Therefore, the findings of this study may be informative for teacher educators as they develop or redesign teacher education programs to meet teachers' needs for mental health teacher training. The result shows that after the intervention out of 80 samples 45 were in excellent group, 30 were in good category and 5 were in average.
\end{abstract}
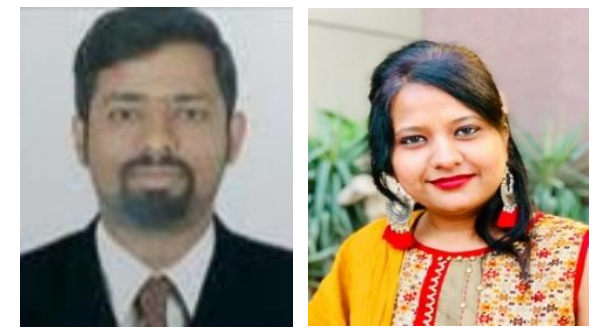

Mr. Jibin Varghese | Dr. Amandeep Kaur

Key Words: Mental health, childhood mental illness. 


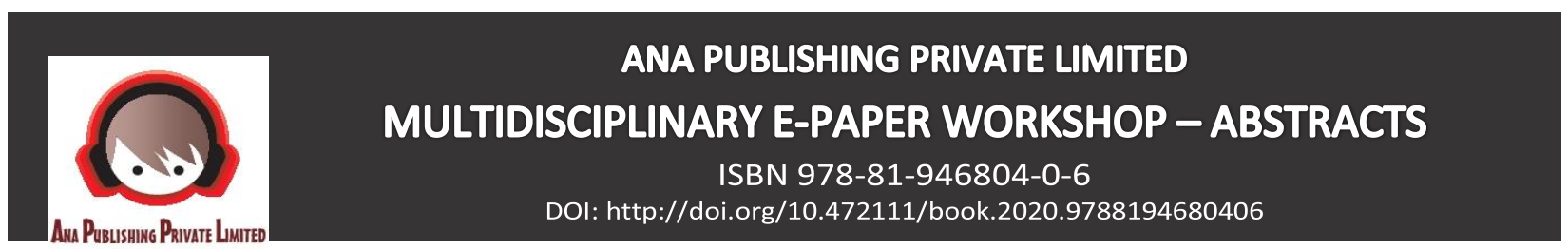

\section{ABSTRACT. 33}

\section{STAYING HEALTHY AT MENOPAUSE AND BEYOND}

Ms. Urmal

Tutor, Department of Medical Surgical Nursing, Government Nursing College, Rajindra Hospital, Patiala, Punjab, India.

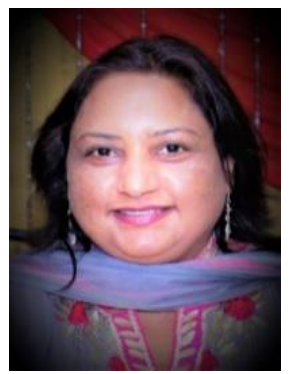

Ms. Urmal

\section{ABSTRACT}

Menopause is an ideal time to begin or reinforce healthy changes in your life. Here are nine areas of your health that might need attention: Keeping a menstrual calendar can help women determine what's normal or abnormal Women should consult a healthcare provider right away if signs of abnormal bleeding patterns occur. Osteoporosis is a major health risk to women after menopause, as age-related bone loss speeds up in the years surrounding menopause. Midlife weight gain in women seems to be mostly related to aging and lifestyle, but the years around menopause are associated with fat gain in the abdomen if women aren't attentive to diet and exercise. Abdominal fat is associated with an increased risk of heart disease. Treatment of sleep disturbances should first focus on improving sleep routine with good sleep hygiene, including a regular sleep schedule, avoiding heavy evening meals, adjusting levels of light, noise, and temperature in the bedroom, and avoiding alcohol, caffeine, and nicotine. Women at increased risk for hormonal headaches and migraines during perimenopause are those who have already had a history of headaches around menstrual periods or when taking oral contraceptives. Hormonal headaches typically stop when menopause is reached and hormone levels are consistently low. Urinary incontinence, which is common during menopause and beyond, is often improved with pelvic floor muscle exercises (Kegel exercises). These involve repeated contraction and relaxation of the muscles that control urine flow, strengthening them so they can better support the bladder. Skin-healthy habits at midlife include: avoiding smoking, stress, and overexposure to sunlight; adequate exercise and sleep; drinking plenty of water; and avoiding hot, soapy showers and baths (which dry out the skin). Practicing good oral hygiene, Gum disease while some risk factors cannot be changed, others can be controlled or modified to create a more heart-healthy lifestyle by following these modifications: Don't smoke, Control blood pressure, Control cholesterol, Control triglycerides, Prevent diabetes, Exercise regularly, Maintain healthy weight or lose weight if overweight, Improve nutrition, Reduce stress. CONCLUSION Menopause, viewed as part of aging, intricately relates the biological, cultural, and social aspects of a woman's life. Women in the cultures described all experience irregular periods and cessation of menses in midlife. However, women relate to the psychological and social aspects of menopause in less universal ways.

Key Words: Menopause, Osteoporosis, Hormones, Lifestyle. 


\section{ABSTRACT. 34 \\ A DESCRIPTIVE STUDY TO ASSESS THE KNOWLEDGE REGARDING DENTAL CARE AMONG THE STUDENTS OF GOVERNMENT ELEMENTARY SCHOOL AT MUDHAL, AMRITSAR WITH A VIEW TO PREPARE INFORMATION GUIDE SHEET Dr. Harleen Kaur Associate Professor, CKD International Nursing College, Amritsar, Punjab, India.}

\section{ABSTRACT}

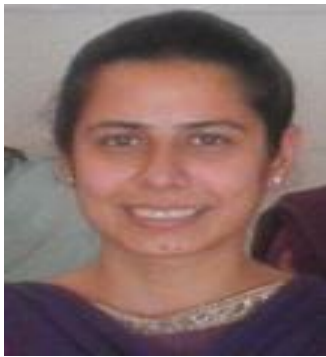

Dr. Harleen Kaur

The mouth provides an ideal environment for pathogen growth and a common site for infection in children. A nurse should be aware enough to educate the children and their parents regarding the problems that could result from the lack of oral hygiene besides teaching them the methods to maintain oral hygiene. Good mouth care is essential for the children and they can feel motivated and enthusiastic if their mouth is clean and free from any bad odour/pain. The researcher believed that this study will help elementary school students to maintain oral hygiene which in turn can be helpful to maintain healthy teeth and healthy intake via mouth. A descriptive study was selected to assess the knowledge of 40 students studying in elementary school at Mudhal, Amritsar. Sample was selected by using purposive sampling technique. Written permission was taken from head of the school and students. Self-structured questionnaire used to collect the data. Questionnaire consisted of 2 parts; Part 1: personal data part 2: knowledge questions. Results revealed that the sample was distributed proportionally gender wise i.e. 20 girls and 20 boys. Mostly (40\%) students' parents were serviceman majority (90\%) students belonged to Sikh and $80 \%$ were vegetarian. It was concluded that boys had more knowledge. Information guide sheet prepared and distributed to the students.

Key Words: Dental care, oral hygiene, elementary students, knowledge. 


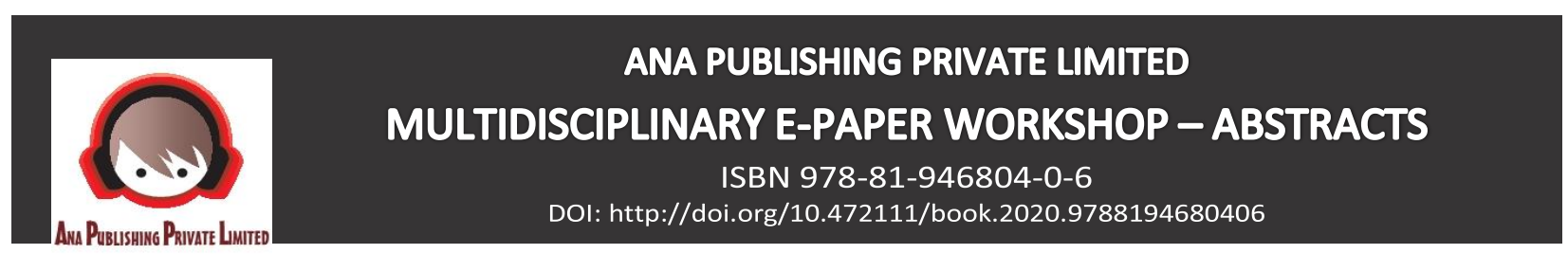

\title{
ABSTRACT. 35 \\ STUDY ON IMPACTS AND MANAGEMENT OF PMS AMONG ADOLESCENT GIRLS IN SELECTED SCHOOL AT CHENNAI \\ Mrs. G. Karpagavalli \\ *Vice Principal, Tagore College of Nursing, Chennai, Tamilnadu, India.
}

\begin{abstract}
PMS is employed to explain physical, cognitive, affective, and behavioural symptoms that occur cyclically throughout the secretary phase of the cycle and resolve quickly at or inside a number of days of the onset of expelling. The first aim of the study was to assess the prevalence, impacts and medical managements of PMS on feminine school students of St, Lourdes Girls Higher Secondary School at Chennai. Methods: A crosssectional study was conducted among consistently selected feminine students of school 2018. A structured and pretested self-administered form was used for knowledge assessment. The collected knowledge was analysed victimization the applied math Package for the Social Sciences, SPSS Package. Result: From the overall population size of 508; a sample size of 300 was drawn. Age of the study participants ranged from 13 to 15 years, with mean age of $13.86 \pm 2$ years. Among the participants, $144(83.2 \%)$ have had a minimum of one PM symptoms with their menstrual amount. The prevalence of PMS per DSM-IV was 77. 0\%. About $118(36.5 \%)$ reported frequent class missing, 78 (22.3\%) exams missing, 109 (30.0\%) low grade marking and $141(49.8 \%)$ of them reported withdrawal from their learning related to their PMS. Only 83(48.0\%) participant's sought after medical treatment for her PMS. The treatment modalities used were pain killers, 63(36.4\%), hot drinks like coffee and tea 176(32.5\%), and seeking medical aid and exercise 124(53.0\%). Binary supplying multivariate analysis discovered average length of 1 cycle of expelling (COR = zero. 20(0.070-0.569) and tutorial performance impairment $(A O R=0.345(0.183-0.653)$ were considerably related to the diagnosing of PMS and use of PMS treatments severally. Conclusion: Our study discovered a high prevalence and negative impact of PMS on Adolescent of St. Lourdes Girls Higher Secondary school. Therefore, health education, acceptable medical treatment and adequate treatment, as a part of the health service, ought to be availed and provided to affected girls.
\end{abstract}

Mrs. G. Karpagavalli

Keywords: Prevalence, Impacts, Medical management, PMS, Adolescent. 

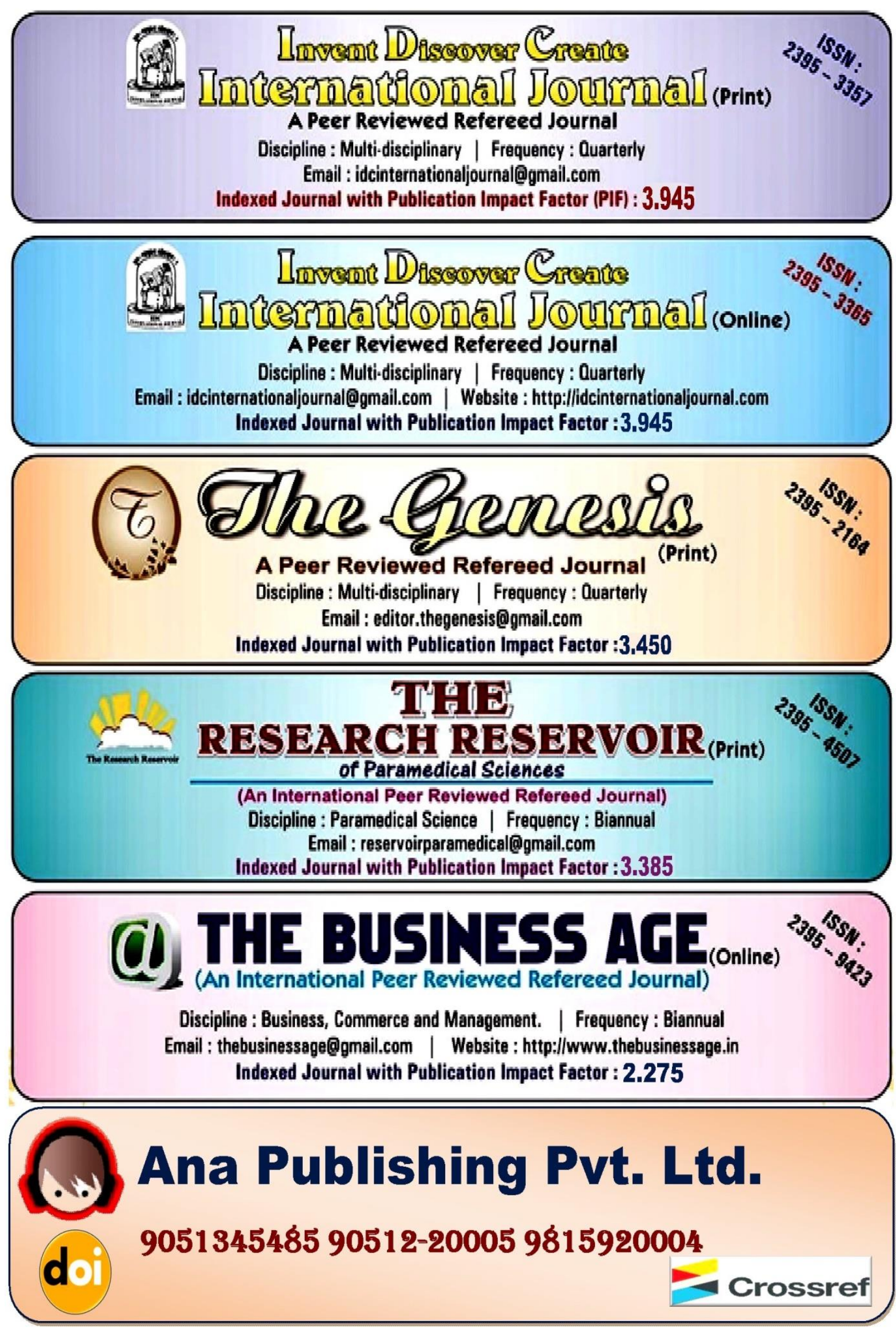